\title{
Group 3 metal complexes supported by tridentate pyridine- and thiophene-linked bis(naphtholate) ligands: synthesis, structure, and use in stereoselective ring-opening polymerization of racemic lactide and $\beta$-butyrolactone $\uparrow$
}

\author{
Ekaterina Grunova, Evgueni Kirillov,* Thierry Roisnel and Jean-François Carpentier*
}

Received 29th September 2009, Accepted 25th November 2009

First published as an Advance Article on the web 7th January 2010

DOI: $10.1039 / \mathrm{b} 920283 \mathrm{~h}$

Scandium, yttrium and lanthanum amido complexes supported by tridentate bis(ortho-silyl-substituted naphtholate)-donor ligands $\left(\left\{\mathrm{ONO}^{\mathrm{SiPh} 3}\right\}^{2-}\right.$ and $\left\{\mathrm{ONO}^{\mathrm{SitBuMe} 2}\right\}^{2-}$, donor $=2,6$-pyridine; $\left\{\mathrm{OSO}^{\mathrm{SiPh} 3}\right\}^{2-}$, donor $=2,5$-thiophene) have been prepared in high yields $(72-96 \%)$ by reaction of the corresponding pro-ligand $\left\{\mathrm{OZO}^{\mathrm{SiR} 3}\right\} \mathrm{H}_{2}$ and $\mathrm{Ln}\left[\mathrm{N}\left(\mathrm{SiHMe}_{2}\right)_{2}\right]_{3}(\mathrm{THF})_{n}$ precursor. The solid-state structures of $\left\{\mathrm{ONO}^{\mathrm{SiPh}}\right\} \mathrm{La}\left[\mathrm{N}\left(\mathrm{SiHMe}_{2}\right)_{2}\right](\mathrm{THF})(\mathbf{3}),\left\{\mathrm{ONO}^{\mathrm{SitBuMe} 2}\right\} \mathrm{Ln}\left[\mathrm{N}\left(\mathrm{SiHMe}_{2}\right)_{2}\right](\mathrm{THF})(\mathrm{Ln}=\mathrm{Sc}, \mathbf{4} ; \mathrm{Y}, \mathbf{5})$ and $\left\{\mathrm{OSO}^{\mathrm{SiPh} 3}\right\} \mathrm{Ln}\left[\mathrm{N}\left(\mathrm{SiHMe}_{2}\right)_{2}\right](\mathrm{THF})(\mathrm{Ln}=\mathrm{Sc}, 7$; La, 9) have been determined by single-crystal X-ray diffraction studies. In all five complexes, the naphtholate rings twist in the same direction from the plane of the pyridine or thiophene linker, to give rise to $C_{\mathrm{s}}$-symmetric (non crystallographic) structures. Compounds 1-9 are single-site initiators for the ring-opening polymerization (ROP) of racemic lactide (rac-LA) at $20^{\circ} \mathrm{C}$, affording poly(lactides)s (PLAs) with relatively narrow polydispersities and molecular weights in good agreement with calculated values. When carried out in THF, the polymerizations afforded heterotactic-enriched PLAs ( $P_{\mathrm{r}}$ up to 0.93 ), while atactic polymers are formed in toluene. Compounds 1-3 and 7-9, having $o-\mathrm{SiPh}_{3}$ substituents on the naphtholate rings, are also active for the ROP of racemic $\beta$-butyrolactone at $20-50{ }^{\circ} \mathrm{C}$, to form syndiotactic-enriched poly(3-hydroxybutyrate)s (PHBs) $\left(P_{\mathrm{r}}\right.$ up to 0.87 ) when using toluene as the solvent, whereas atactic polymers were obtained in THF. The nature of the metal center (Sc, Y, La), the central linker in the ligand framework (pyridine, thiophene), and the ortho-silyl substituent $\left(\mathrm{SiPh}_{3}, \mathrm{SiMe}_{2} t \mathrm{Bu}\right)$ significantly affect the degree of stereocontrol in those polymerizations.

\section{Introduction}

Phenolates (aryloxides) combined with other donor atoms $(\mathrm{N}$, $\mathrm{S}, \mathrm{O} \ldots)$ are common multidentate ligands for early transition metals, ${ }^{1}$ which have met with much success in the development of post(non)-metallocenes for polymerization catalysis. Discrete group 3-6 metal complexes bearing various bidentate, ${ }^{2}$ tridentate, ${ }^{3}$ and tetradentate ${ }^{4}$ phenolate-based ligands have demonstrated high performances (i.e., catalytic activity, degree of control, stereoselectivity) in the oligomerization/polymerization of ethylene and $\alpha$-olefins. ${ }^{5}$ More recently, this class of ligands, particularly the bis(phenolate)s, has been investigated in the ring-opening polymerization (ROP) of cyclic esters, such as lactide, for the preparation of biocompatible polymers, ${ }^{6}$ mostly in combination

Catalysis and Organometallics, UMR 6226 Sciences Chimiques de Rennes, CNRS-University of Rennes 1, 35042, Rennes, Cedex, (France). E-mail: jean-francois.carpentier@univ-rennes1.fr, evgueni.kirillov@univrennes1.fr; Fax: (+33)(0)223-236-939

$\dagger$ Electronic supplementary information (ESI) available: cif files for crystal structure determinations of complexes 3-5, 7, 9 and 10, ORTEP views and main bond distances and angles for complexes 3, 5 and 9, and representative ${ }^{1} \mathrm{H}$ NMR and ${ }^{13} \mathrm{C}$ NMR spectra of PLA and PHB. CCDC reference numbers 752787, 752788, 752789. 752790, 752791 and 752792 . For ESI and crystallographic data in CIF or other electronic format see DOI: $10.1039 / \mathrm{b} 920283 \mathrm{~h}$ with group 3 (lanthanides) ${ }^{7}$ and also to a lesser extent group 4 metals. $^{8}$

Of particular interest are tridentate ligands $\{\mathrm{OZO}\}^{2-}$ where a rigid flat central donor of the " $\mathrm{L}$ "-type is flanked by two phenolate rings, because such " $\mathrm{LX}_{2}$ "-type ligands can confer various symmetries at the metal center. For instance, bis(phenolate) ligands having a 2,6-pyridine, 2,5-furan or 2,5-thiophene linker have been shown to bind to iron(III), copper(II), aluminium(III), ${ }^{9}$ and Ti(IV) ${ }^{3 \mathrm{f}}$ in a $C_{2}(\mathrm{rac})$ fashion, while they bind to zirconium(IV) $)^{3 \mathrm{de}, \mathrm{f}}$ and boron(III) ${ }^{10}$ in a $C_{\mathrm{s}}$ (meso) or $C_{1}$ fashion. Static or dynamic control over these diverse symmetries is of great interest in polymerization catalysis, as it may eventually give rise to polymers with stereoregular microstructures. ${ }^{5,6}$ On this principle, we have recently prepared sterically demanding silyl ortho-substituted tridentate 2,6bis(naphtholate)pyridine $\left(\left\{\mathrm{ONO}^{\mathrm{SiR} 3}\right\}^{2-}, \mathrm{SiR}_{3}=\mathrm{SiPh}_{3}, \mathrm{SiMe}_{2} t \mathrm{Bu}\right)$ and 2,5-bis(naphtholate)thiophene $\left(\left\{\mathrm{OSO}^{\mathrm{Siph} 3}\right\}^{2-}\right)$ ligands and studied their corresponding group 4 metal (Ti, Zr, Hf) complexes. ${ }^{11}$ An anticipated key feature of these ligands was the possibility for firm stereoselective coordination to the metal center provided by the non-coplanar orientation of the bridging heterocyclic and adjacent naphthoxy groups, due to steric repulsion between protons at meta and 8-positions ${ }^{12}$ of these moieties, respectively. In fact, $\mathrm{X}$-ray diffraction studies revealed that, in the solid state, the latter group 4 metal complexes adopt either rac-like or meso-like binding of the ligand, while VT NMR spectroscopy studies in toluene 


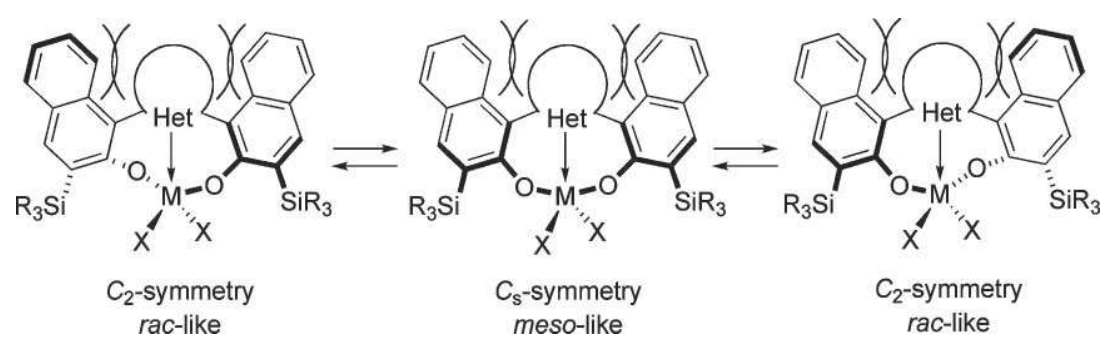

Scheme 1 Examples of common geometries in $\left\{\mathrm{OZO}^{\mathrm{SiR} 3}\right\} \mathrm{M}$ complexes and corresponding dynamic processes.

solution indicated that such complexes exist as rac and meso stereoisomers that interconvert relatively easily (activation parameters: $\Delta H^{\ddagger}=12.9(7)-13.4(8) \mathrm{kcal} \mathrm{mol}^{-1}$ and $\Delta S^{\ddagger}=-3(1)$ to $-7(1)$ cal $\mathrm{mol}^{-1} \mathrm{~K}^{-1}$ ) (Scheme 1). Yet, these systems showed disappointing catalytic performance in propylene polymerization (upon activation with MAO), leading at best to atactic oligomers with poor activity.

This naphthoxy-based $\left\{\mathrm{OZO}^{\mathrm{SiR} 3}\right\}^{2-}$ ligand platform is also of potential interest to group 3 metal chemistry and related ROP catalysis of chiral (racemic) cyclic esters, for several reasons: First, such chelating ligands should accommodate metal centers with quite different ionic radii; this should allow studying in more detail the impact of the latter parameter, as well as the influence of hard $(Z=\mathrm{N}) v s$. soft $(Z=\mathrm{S})$ donating heteroatom and ortho-silyl groups over the polymerization course (activity, control). Such data are still necessary because no clear rationale exists yet to account for the reported behavior of group 3 metal catalysts in ROP of cyclic esters. ${ }^{6}$ Second, yet much more challenging, if complexes with different symmetries (e.g., with a $C_{2^{-}}, C_{\mathrm{s}^{-}}$ symmetric ligand) are attainable and if a reasonably easy dynamic interconversion between such geometrically stable isomers, e.g. rac and meso occurs, original multiblock microstructures (varying by the nature or degree of tacticity) could be accessed via "oscillating" polymerization.

Accordingly, we describe herein the coordination chemistry of $\left\{\mathrm{OZO}^{\mathrm{SiR} 3}\right\}^{2-}$ ligands with group 3 metals $(\mathrm{Ln}=\mathrm{Sc}, \mathrm{Y}$, $\mathrm{La})$. The performance of the amido compounds $\left\{\mathrm{OZO}^{\mathrm{SiR} 3}\right\}$ $\mathrm{Ln}\left[\mathrm{N}\left(\mathrm{SiHMe}_{2}\right)_{2}\right](\mathrm{THF})$ in the stereoselective ROP of racemic lactide and racemic- $\beta$-butyrolactone ${ }^{13}$ is also reported.

\section{Results and discussion}

Preparation of scandium, yttrium and lanthanum complexes supported by tridentate bis(naphtholate)-donor ligands

Scandium, yttrium and lanthanum complexes were prepared by amine elimination in reaction of the corresponding tris(dimethylsilyl)amido metal group 3 precursors and bis(naphthol)-donor pro-ligands $\left\{\mathrm{OZO}^{\mathrm{SiR} 3}\right\} \mathrm{H}_{2}{ }^{11}$ (Scheme 2). The reactions proceeded cleanly at room temperature in benzene or toluene solutions, as evidenced by NMR monitoring. Complexes 1-5 and 7-9 were isolated in 72-96\% yields as pale yellow microcrystalline powders, which are air-sensitive and readily soluble in most usual organic solvents. Complex $\mathbf{6}$ was generated in situ for further use in catalysis (vide infra), but not isolated.

A coordinated THF molecule was systematically observed by ${ }^{1} \mathrm{H}$ and ${ }^{13} \mathrm{C}$ NMR spectroscopy for all complexes. This observation, in line with the mononuclear structures in the solid state for such amido group 3 metal compounds (vide infra) and the unlikely bridging modes of the bulky $\mathrm{N}\left(\mathrm{SiHMe}_{2}\right)_{2}{ }^{-}$and $\left\{\mathrm{OZO}^{\mathrm{SiR} 3}\right\}^{2-}$ ligands, suggests that $\left\{\mathrm{OZO}^{\mathrm{SiR} 3}\right\} \mathrm{Ln}\left[\mathrm{N}\left(\mathrm{SiHMe}_{2}\right)_{2}\right](\mathrm{THF})$ compounds are mononuclear and five-coordinate in benzene or toluene solution. The chemical shifts for the $\operatorname{Si} H(\delta 4.29-4.76 \mathrm{ppm}$ at $298 \mathrm{~K}$ in benzene- $d_{6}$ ), which are shifted upfield compared to the chemical shift in the corresponding $\left[\mathrm{Ln}\left\{\mathrm{N}\left(\mathrm{SiHMe}_{2}\right)_{2}\right\}_{3}(\mathrm{THF})_{2}\right]$ precursors $(\delta 4.94-5.02 \mathrm{ppm})$, argue against a significant $\beta(\mathrm{Si}-\mathrm{H})$ agostic interaction with the metal center in solution (vide infra) ${ }^{14}$

As mentioned in the Introduction section, these bis(naphtholate)-donor ligands can achieve, in principle, a variety of binding geometries, two of them being most common $\left(C_{2}, C_{\mathrm{s}}\right.$; Scheme 3$){ }^{3 \mathrm{f}, 11,15}$ that should be distinguishable by NMR

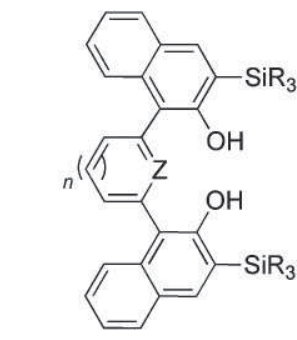

$\left\{\mathrm{OZO}^{\mathrm{R}}\right\}_{\mathrm{H}_{2}}$

$\mathrm{Z}=\mathrm{N}, n=1, \mathrm{SiR}_{3}=\mathrm{SiPh}_{3}, \mathrm{SitBuMe}_{2}$

$\mathrm{Z}=\mathrm{S}, n=0, \mathrm{SiR}_{3}=\mathrm{SiPh}_{3}$
$\operatorname{Ln}\left(\mathrm{N}\left(\mathrm{SiHMe}_{2}\right)_{2}\right)_{3}(\mathrm{THF})_{2}$

benzene or toluene, $20^{\circ} \mathrm{C}$

$-2 \mathrm{HN}\left(\mathrm{SiHMe}_{2}\right)_{2}$

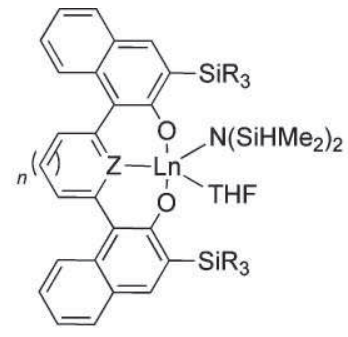

$\begin{array}{ll}\left\{\mathrm{ONO}^{\mathrm{SiPh}} 3\right\} \mathrm{Ln}\left[\mathrm{N}\left(\mathrm{SiHMe}_{2}\right)_{2}\right](\mathrm{THF}) & \mathrm{Ln}=\mathrm{Sc}(\mathbf{1}), \mathrm{Y}(\mathbf{2}), \mathrm{La}(\mathbf{3}) \\ \left\{\mathrm{ONO}^{\mathrm{SitBuMe}}\right\} \mathrm{Ln}\left[\mathrm{N}\left(\mathrm{SiHMe}_{2}\right)_{2}\right](\mathrm{THF}) & \mathrm{Ln}=\mathrm{Sc}(\mathbf{4}), \mathrm{Y}(\mathbf{5}), \mathrm{La}(\mathbf{6}) \\ \left\{\mathrm{OSO}^{\mathrm{SiPh} 3}\right\} \mathrm{Ln}\left[\mathrm{N}\left(\mathrm{SiHMe}_{2}\right)_{2}\right](\mathrm{THF}) & \mathrm{Ln}=\mathrm{Sc}(\mathbf{7}), \mathrm{Y}(\mathbf{8}), \mathrm{La}(\mathbf{9})\end{array}$

Scheme 2 


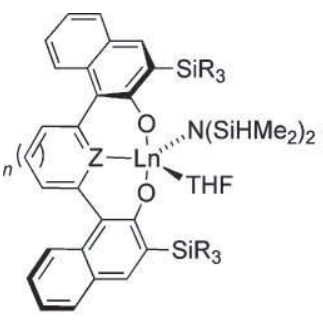

( $C_{2}$-symmetric ligand)

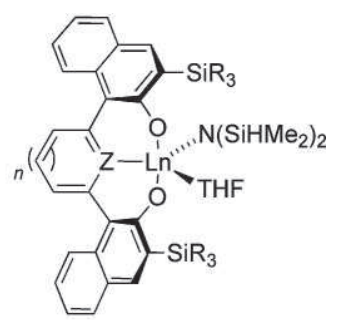

$\left(C_{\mathrm{s}}\right.$-symmetric ligand)
Scheme 3 Geometries observed in $\left\{\mathrm{OZO}^{\mathrm{SiR} 3}\right\} \mathrm{Ln}\left[\mathrm{N}\left(\mathrm{SiHMe}_{2}\right)_{2}\right](\mathrm{THF})$ complexes.

spectroscopy. Such analysis is, however, hampered in the present case by the complicated pattern of resonances associated with the naphtholate rings in the ${ }^{1} \mathrm{H}$ NMR spectra, especially when $\mathrm{SiPh}_{3}$ substituents are present. More informative data were obtained from variable-temperature NMR experiments on the complexes bearing $\mathrm{Si} t \mathrm{BuMe}_{2}$ substituents at the naphtholate rings. In fact, the ${ }^{1} \mathrm{H}$ NMR data for both $\mathbf{4}$ and $\mathbf{5}$ are consistent with the existence, on the NMR time scale, of a single species with a $C_{\mathrm{s}}$ symmetrically bound ligand ${ }^{15}$ in toluene in the temperature range 223-338 K (Fig. 1 and 2). No additional resonances, in particular in the aromatic region, were observed that could account for the presence [within experimental accuracy] of a second stereoisomer. Relevant features of these VT NMR spectra include, for both compounds, one sharp singlet resonance [b] for the methyl hydrogens of the $\mathrm{Si} t \mathrm{BuMe} \mathrm{M}_{2}$ groups in the high temperature spectra which decoalesced to give two sharp singlet resonances in the low temperature spectra. At the same time, as best seen in yttrium compound 5: the $\alpha$-THF methylene hydrogens appear as a [broadened] singlet [e] in the high temperature spectrum and decoalesced in two well-resolved resonances $\left[\mathrm{e} / \mathrm{e}^{\prime}\right]$ at $233 \mathrm{~K}^{16}$ We tentatively interpret those dynamic phenomena, which are reversible upon increasing or decreasing the temperature, in relation with rotation of the coordinated THF molecule (and fluxionality within the latter cycle). Site exchange (of THF and the amide ligands, which would imply THF dissociation) seems unlikely as this would generate species in different environments that should be distinguished by ${ }^{1} \mathrm{H}$ NMR at low temperature, which is not the case (vide supra).

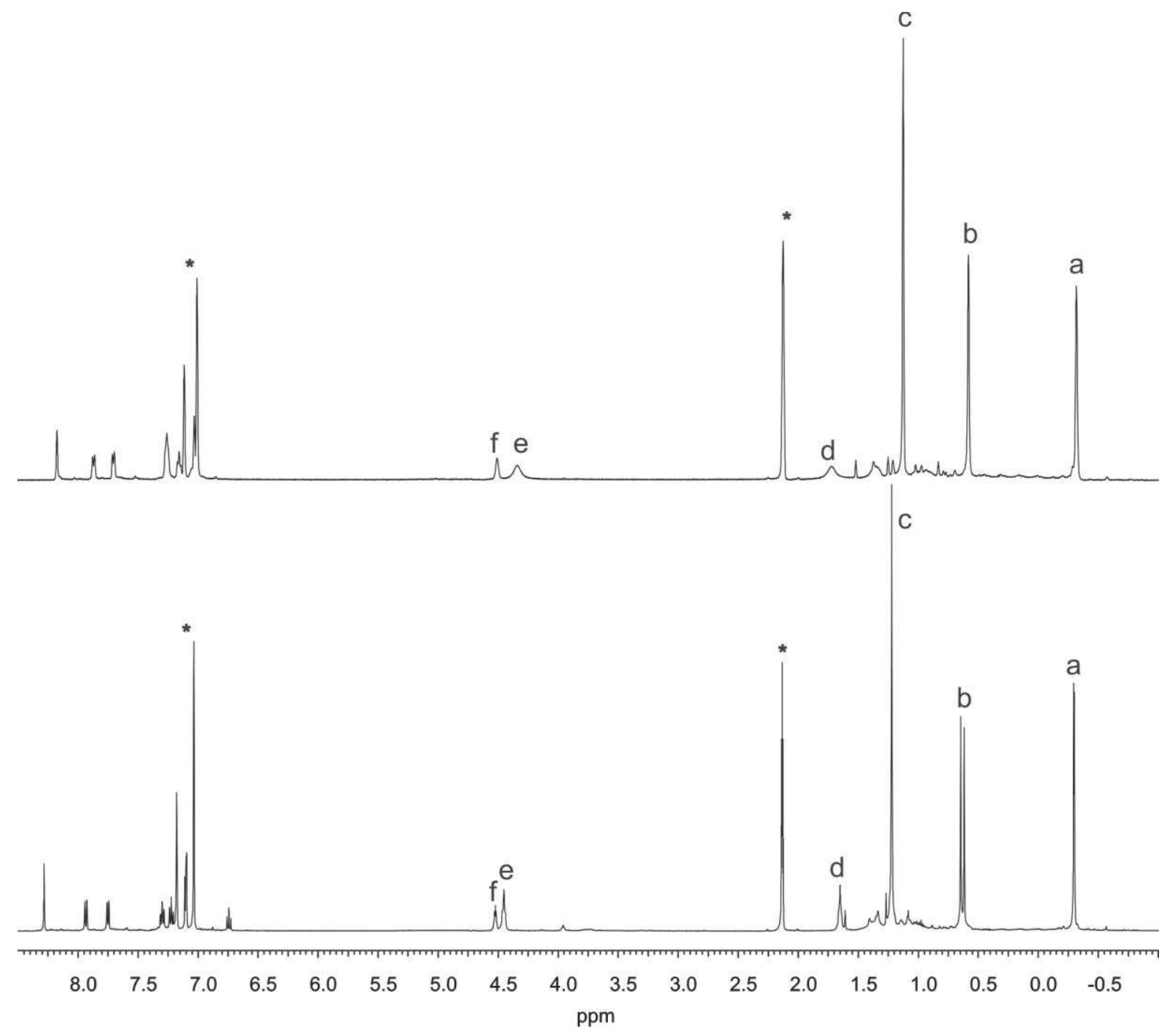

Fig. 1 VT- ${ }^{1} \mathrm{H}$ NMR spectra $\left(500 \mathrm{MHz}\right.$, toluene- $\left.d_{8}\right)$ of $\left\{\mathrm{ONO}^{\mathrm{SitBuMe} 2}\right\} \mathrm{Sc}\left[\mathrm{N}\left(\mathrm{SiHMe}_{2}\right)_{2}\right](\mathrm{THF})(4)$; bottom, $223 \mathrm{~K}$; top, $338 \mathrm{~K}$. (a) $\mathrm{SiH} M e_{2}$; (b) $\mathrm{Sit} \mathrm{Bu} M e_{2}$; (c) $\mathrm{Si} t B u \mathrm{Me}_{2}$; (d) $\beta$-THF; (e) $\alpha$-THF; (f) $\mathrm{SiHMe}_{2}$ (* refers to residual solvent resonances). 


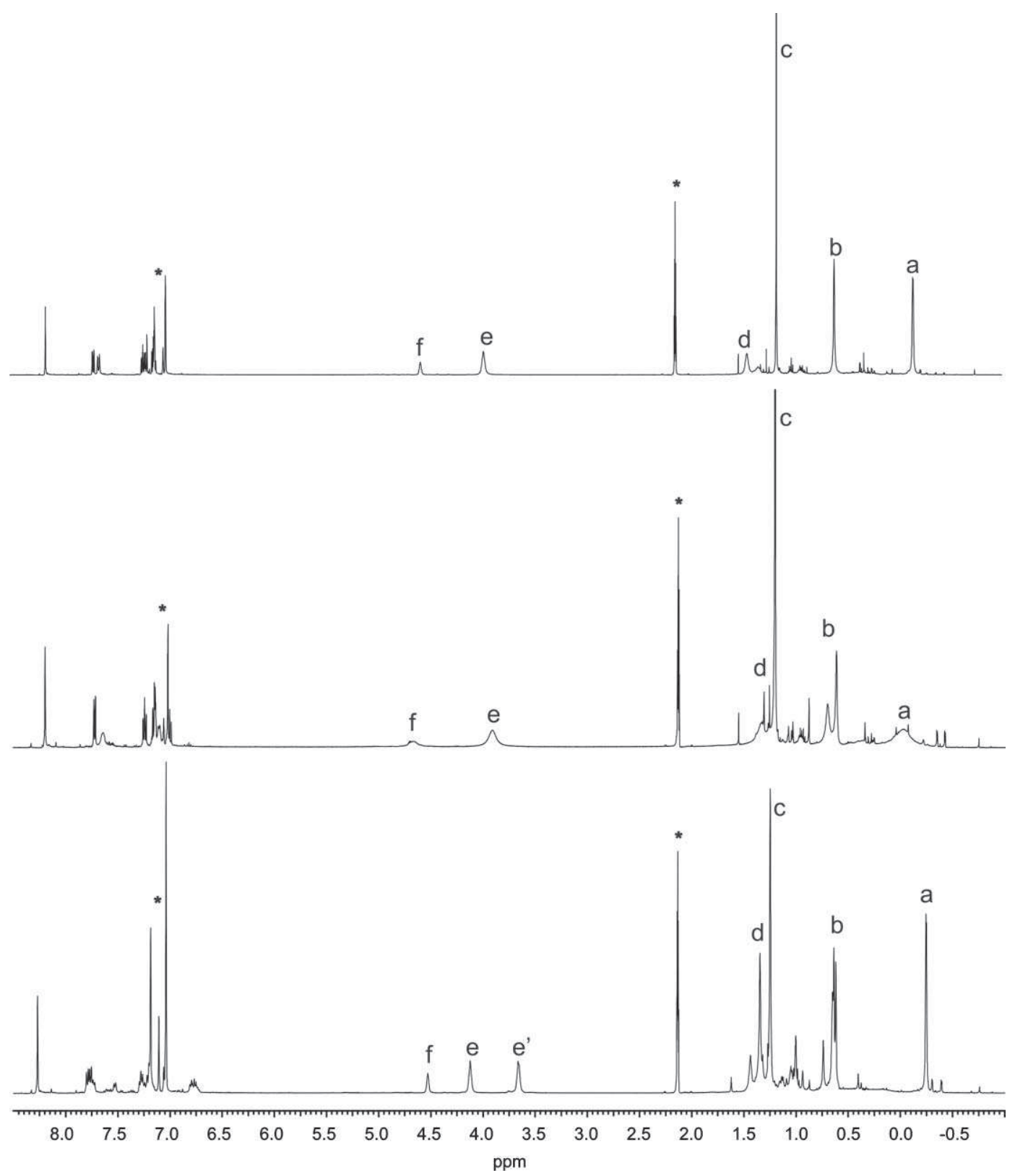

Fig. 2 VT- ${ }^{1} \mathrm{H}$ NMR spectra (500 MHz, toluene- $\left.d_{8}\right)$ of $\left\{\mathrm{ONO}^{\mathrm{SitBuMe} 2}\right\} \mathrm{Y}\left[\mathrm{N}\left(\mathrm{SiHMe}_{2}\right)_{2}\right](\mathrm{THF})(\mathbf{5})$; bottom, $233 \mathrm{~K}$; middle, $296 \mathrm{~K}$; top, $338 \mathrm{~K}$. (a) SiHMe $e_{2}$; (b) $\mathrm{Sit} B \mathrm{BuMe} e_{2}$; (c) $\mathrm{Si} t B u \mathrm{Me}_{2}$; (d) $\beta$-THF; (e) $\alpha$-THF; (f) $\mathrm{SiHMe}_{2}$ (* refers to residual solvent resonances).

Solid state structures of scandium, yttrium and lanthanum complexes supported by tridentate bis(naphtholate)-donor ligands

Determination of the binding modes of the bis(naphtholate)donor ligands in these complexes is more straightforward from single-crystal X-ray diffraction studies, although these observations in the solid state may not necessarily reflect the actual geometries in solution. Crystals suitable for X-ray diffraction studies were successfully grown from concentrated benzene solution at room temperature for compounds 3-5, 7, and $\mathbf{9}$. The main crystallographic details are reported in Table 1. The molecular structures of $\mathbf{4}$ and $\mathbf{7}$, and selected bond distances and angles for these compounds are given in Fig. 3 and 4, respectively. Structures and geometric factors for the other compounds are quite similar and available as ESI. $\dagger$
All five complexes show a distorted trigonal-bipyramidal geometry at the metal center, which is five-coordinated by the $\left\{\mathrm{OZO}^{\mathrm{SiR} 3}\right\}^{2-}$ ligand, the THF molecule and the dimethylsilylamido group. Yet, $\beta$-agostic interactions between one of the $\mathrm{Si}-\mathrm{H}$ of the latter amido group and the metal center are evidenced in all complexes by close $\mathrm{M} \cdots \mathrm{H}(\mathrm{Si})$ contacts $(2.818-3.129 \AA)$ and $\mathrm{M} \cdots \mathrm{Si}(\mathrm{H})$ contacts (3.134-3.370 $\mathrm{A})$ (Table 2). These agostic interactions are confirmed by the observation of a more obtuse $\mathrm{M}-\mathrm{Si}-\mathrm{N}$ bond angle $\left(102.4(5)-116.4(2)^{\circ}\right)$. These interactions remain, however, overall weak; this is attested by the $\mathrm{Si}-\mathrm{N}-$ $\mathrm{Si}$ bond angles of $122.1(2)-130.6(2)^{\circ}$ that are slightly larger than the angle of $120^{\circ}$ for ideal $\mathrm{sp}^{2}$ hybridization and that fall into the upper range of values reported for $\mathrm{Si}-\mathrm{N}-\mathrm{Si}$ angles $\left(119.93-129.58^{\circ}\right) .{ }^{17}$ 
Table 1 Summary of crystal and refinement data for compounds $\mathbf{3 - 5 , 7 , 9}$ and $\mathbf{1 0}$ (all data were collected at $100 \mathrm{~K}$ )

\begin{tabular}{|c|c|c|c|c|c|c|}
\hline & 3 & $4 \cdot 2.5\left(\mathrm{C}_{6} \mathrm{H}_{6}\right)$ & $\mathbf{5} \cdot 2.5\left(\mathrm{C}_{6} \mathrm{H}_{6}\right)$ & $7 \cdot 4\left(\mathrm{C}_{6} \mathrm{H}_{6}\right)$ & 9.0.5 $\left(\mathrm{C}_{6} \mathrm{H}_{14}\right)$ & $\mathbf{1 0} \cdot 4\left(\mathrm{C}_{6} \mathrm{H}_{6}\right)$ \\
\hline Empirical formula & $\mathrm{C}_{69} \mathrm{H}_{65} \mathrm{LaN}_{2} \mathrm{O}_{3} \mathrm{Si}_{4}$ & $\begin{array}{l}\mathrm{C}_{45} \mathrm{H}_{65} \mathrm{~N}_{2} \mathrm{O}_{3} \mathrm{ScSi}_{4} . \\
2.5\left(\mathrm{C}_{6} \mathrm{H}_{6}\right)\end{array}$ & $\begin{array}{l}\mathrm{C}_{45} \mathrm{H}_{65} \mathrm{YN}_{2} \mathrm{O}_{3} \mathrm{Si}_{4} . \\
2.5\left(\mathrm{C}_{6} \mathrm{H}_{6}\right)\end{array}$ & $\begin{array}{l}\mathrm{C}_{68} \mathrm{H}_{64} \mathrm{NO}_{3} \mathrm{SScSi}_{4} . \\
4\left(\mathrm{C}_{6} \mathrm{H}_{6}\right)\end{array}$ & $\begin{array}{l}\mathrm{C}_{68} \mathrm{H}_{64} \mathrm{LaNO}_{3} \mathrm{SSi}_{4} . \\
\left.0.5\left(\mathrm{C}_{6} \mathrm{H}_{14}\right)\right)\end{array}$ & $\begin{array}{l}\mathrm{C}_{126} \mathrm{H}_{100} \mathrm{La}_{2} \mathrm{~N}_{2} \mathrm{O}_{9} \mathrm{Si}_{4} . \\
4\left(\mathrm{C}_{6} \mathrm{H}_{6}\right)\end{array}$ \\
\hline Formula weight & 1221.5 & 1034.58 & 1078.53 & 1445.01 & 1269.62 & 2488.69 \\
\hline Crystal system & Triclinic & Monoclinic & Monoclinic & Triclinic & Monoclinic & Orthorhombic \\
\hline Space group & $P-1$ & $P 2_{1} / n$ & $P 2_{1} / n$ & $P-1$ & $C 2 / c$ & $P c a b$ \\
\hline$a / \AA$ & $11.5427(13)$ & $11.2092(6)$ & $11.2947(9)$ & $12.3960(7)$ & $38.9355(14)$ & $22.4713(9)$ \\
\hline$b / \AA$ & $13.2146(15)$ & $23.4248(12)$ & $23.4235(17)$ & $15.9382(10)$ & $15.5687(6)$ & $29.6425(13)$ \\
\hline$c / \AA$ & $21.910(3)$ & $22.6197(11)$ & $22.7434(17)$ & $21.8083(14)$ & $22.9647(8)$ & $39.1800(14)$ \\
\hline$\alpha\left(^{\circ}\right)$ & $72.404(6)$ & 90 & 90 & $103.867(4)$ & 90 & 90 \\
\hline$\beta\left(^{\circ}\right)$ & $88.235(6)$ & $94.018(3)$ & $93.324(4)$ & $98.581(4)$ & $113.803(2)$ & 90 \\
\hline$\gamma\left({ }^{\circ}\right)$ & $76.123(7)$ & 90 & 90 & $106.022(3)$ & 90 & 90 \\
\hline Volume/ $\AA^{3}$ & $3089.5(7)$ & $5924.7(5)$ & $6006.9(8)$ & $3912.1(4)$ & $12736.5(8)$ & $26098.0(18)$ \\
\hline$Z$ & 2 & 4 & 4 & 2 & 8 & 8 \\
\hline Density, $\mathrm{Mg} \mathrm{m}^{-3}$ & 1.313 & 1.160 & 1.193 & 1.227 & 1.324 & 1.264 \\
\hline$\mu / \mathrm{mm}^{-1}$ & 0.816 & 0.248 & 1.093 & 0.233 & 0.826 & 0.741 \\
\hline$F(000)$ & 1260 & 2220 & 2292 & 1528 & 5256 & 10192 \\
\hline Crystal size/mm & $0.20 \times 0.05 \times 0.04$ & $0.52 \times 0.30 \times 0.25$ & $0.42 \times 0.38 \times 0.21$ & $0.16 \times 0.10 \times 0.06$ & $0.28 \times 0.17 \times 0.14$ & $0.20 \times 0.20 \times 0.065$ \\
\hline$\theta$ range, deg & 2.53 to 21.42 & 3.48 to 27.48 & 3.44 to 27.47 & 3.42 to 27.48 & 3.41 to 27.48 & 3.41 to 27.45 \\
\hline Limiting indices & $\begin{array}{l}-14 \leq h \leq 14 \\
-17 \leq k \leq 15 \\
-28 \leq l \leq 28\end{array}$ & $\begin{array}{l}-14 \leq h \leq 13 \\
-30 \leq k \leq 30 \\
-29 \leq l \leq 29\end{array}$ & $\begin{array}{l}-14 \leq h \leq 14 \\
-23 \leq k \leq 30 \\
-29 \leq l \leq 29\end{array}$ & $\begin{array}{l}-16 \leq h \leq 15 \\
-20 \leq k \leq 20 \\
-28 \leq l \leq 27\end{array}$ & $\begin{array}{l}-50 \leq h \leq 35 \\
-20 \leq k \leq 20 \\
-29 \leq l \leq 29\end{array}$ & $\begin{array}{l}-29 \leq h \leq 24,-37 \leq \\
k \leq 38,-27 \leq l \leq 50\end{array}$ \\
\hline Reflec. collected & 14021 & $6347 \overline{9}$ & 52124 & 43820 & 67600 & 151425 \\
\hline$R_{\text {int }}$ & 0.1200 & 0.0538 & 0.0534 & 0.1075 & 0.0618 & 0.1008 \\
\hline $\begin{array}{l}\text { Reflec. unique } \\
{[I>2 \sigma(I)]}\end{array}$ & 9954 & 13476 & 13601 & 17816 & 14447 & 29729 \\
\hline $\begin{array}{l}\text { Data/restraints/ } \\
\text { param. }\end{array}$ & $14021 / 0 / 702$ & $13476 / 0 / 651$ & $13601 / 0 / 691$ & $17816 / 0 / 917$ & $14447 / 2 / 699$ & $29729 / 477 / 1024$ \\
\hline $\begin{array}{l}\text { Goodness-of-fit } \\
\text { on } F^{2}\end{array}$ & 1.201 & 1.122 & 1.03 & 1.058 & 1.020 & 1.032 \\
\hline $\begin{array}{l}R_{1}[I>2 \sigma(I)] \\
\text { (all data) }\end{array}$ & $0.1307(0.1753)$ & $0.0635(0.0754)$ & $0.0413(0.0713)$ & $0.1013(0.1762)$ & $0.0426(0.0693)$ & $0.0828(0.1255)$ \\
\hline $\begin{array}{l}\text { w } R_{2}[I>2 \sigma(I)] \\
\text { (all data) }\end{array}$ & $0.2464(0.2678)$ & $0.1121(0.1174)$ & $0.0848(0.0943)$ & $0.1621(0.1917)$ & $0.0900(0.1018)$ & $0.1829(0.2032)$ \\
\hline Largest diff. e $\mathrm{A}^{-3}$ & 2.444 and -4.305 & 0.528 and -0.688 & 0.735 and -0.591 & 0.545 and -0.577 & 1.605 and -0.996 & 1.984 and -1.388 \\
\hline
\end{tabular}

Table 2 Close contacts $(\AA)$ and angles (deg) attesting of $\mathrm{Si}-\mathrm{H} \cdots \mathrm{M}$ agostic interactions in compounds $3-5,7$ and 9

\begin{tabular}{lllll}
\hline Compound & $\mathrm{M} \cdots \mathrm{H}(\mathrm{Si})$ & $\mathrm{M} \cdots \mathrm{Si}$ & $\mathrm{M}-\mathrm{Si}-\mathrm{N}$ & $\mathrm{Si}-\mathrm{N}-\mathrm{Si}$ \\
\hline $\mathbf{3}$ & 2.818 & 3.210 & $102.4(5)$ & $119.3(7)$ \\
$\mathbf{4}$ & 4.240 & 3.737 & $119.2(7)$ & \\
& 3.095 & 3.213 & $116.4(1)$ & $123.5(1)$ \\
$\mathbf{5}$ & 3.912 & 3.264 & $119.9(1)$ & \\
& 2.966 & 3.247 & $111.4(1)$ & $130.1(2)$ \\
$\mathbf{7}$ & 4.040 & 3.443 & $116.7(2)$ & \\
$\mathbf{9}$ & 3.023 & 3.134 & $112.6(2)$ & $122.1(2)$ \\
& 3.428 & 3.336 & $125.3(2)$ & $130.6(2)$ \\
\hline
\end{tabular}

In all five complexes, the naphtholate rings twist in the same direction from the plane of the linker to give rise to $C_{\mathrm{s}}$-symmetric (non crystallographic) structures. The degree of twisting, as measured by the dihedral angle between the $\mathrm{M}-\mathrm{O}$ bonds and the plane of the linker, ranges from 49 to $84^{\circ}$. In some complexes, this degree of twisting may differ considerably within the two naphtholate rings. This difference in the twist angles is especially marked for the lanthanum complexes $\left(\mathbf{3}, 49.2\right.$ and $63.3^{\circ} ; \mathbf{9}, 73.3$ and $84.0^{\circ}$ ). This might just reflect the more pronounced influence of crystal packing around a large and therefore less sterically hindered metal center. ${ }^{18}$ For a given ligand, i.e., $\left\{\mathrm{ONO}^{\mathrm{Siph} 3}\right\}^{2-}$, the twist angles slightly increase from scandium $\left(4,52.4\right.$ and $\left.55.0^{\circ}\right)$ to yttrium $\left(5,56.5\right.$ and $\left.60.4^{\circ}\right)$. As indicated by the minimal difference between the twist angles, the structural features of the naphtholate rings in scandium complexes $\left\{\mathrm{ONO}^{\mathrm{SitBuMe} 2}\right\} \mathrm{Sc}\left[\mathrm{N}\left(\mathrm{SiHMe}_{2}\right)_{2}\right](\mathrm{THF})$ $\left(4,52.4\right.$ and $\left.55.0^{\circ}\right)$ and $\left\{\mathrm{OSO}^{\mathrm{SiPh} 3}\right\} \mathrm{Sc}\left[\mathrm{N}\left(\mathrm{SiHMe}_{2}\right)_{2}\right](\mathrm{THF})(\mathbf{7}, 51.9$ and $\left.53.3^{\circ}\right)$ are very similar. Yet, as illustrated in Fig. 3 and 4 , the pyridine and thiophene linkers coordinate quite differently in those complexes: the thiophene ring is almost perpendicular to the $\mathrm{M}-\mathrm{S}$ vector (dihedral angle: $\mathbf{7}, 88.3^{\circ} ; \mathbf{9}, 73.9^{\circ}$ ), while the pyridine ring is only slightly deviated from the $\mathrm{M}-\mathrm{N}$ vector (dihedral angle: $\mathbf{3}$, $156.6^{\circ} ; \mathbf{4}, 152.8^{\circ} ; \mathbf{5}, 152.5^{\circ}$ ). Similar features were observed for group 4 metal complexes of bis(phenolate)-donor ligands. ${ }^{3 \mathrm{f}}$

The selective (at least in the solid state) $C_{\mathrm{s}}$ binding mode of these bis(naphtholate)-donor ligands with group 3 metals is in line with the $C_{\mathrm{s}}$ binding mode of analogous $\mathrm{CMe}_{3}$ and $\mathrm{CEt}_{3}$ orthosubstituted bis(phenolate)-donor ligands (donor $=$ pyridine, thiophene, furan) observed by Bercaw et al. in a series of tantalum(v) complexes. ${ }^{19}$ On the other hand, it is in contrast with the $C_{2}$ or $C_{1}$ binding mode ${ }^{15}$ of the latter bis(phenolate)-donor ligands ${ }^{3 f}$ and present bis(naphtholate)-donor ligands ${ }^{11}$ in five-coordinate dibenzyl titanium(IV), zirconium(IV) and hafnium(IV) complexes. Only for six-coordinate group 4 metal complexes, which adopt a distorted octahedral geometry, those bis(phenolate)-donor and bis(naphtholate)-donor ligands gave rise to a $C_{\mathrm{s}}$ binding mode. $^{3 \mathrm{~d}, \mathrm{e}, \mathrm{f}, 11}$ These observations indicate that the binding mode of this type of $\mathrm{LX}_{2}$ ligand is not simply controlled either by the 


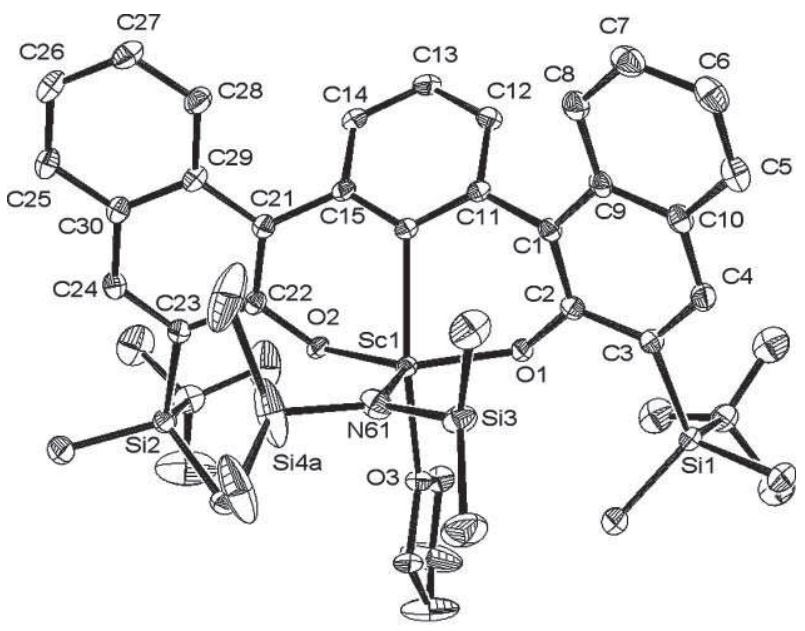

(a)

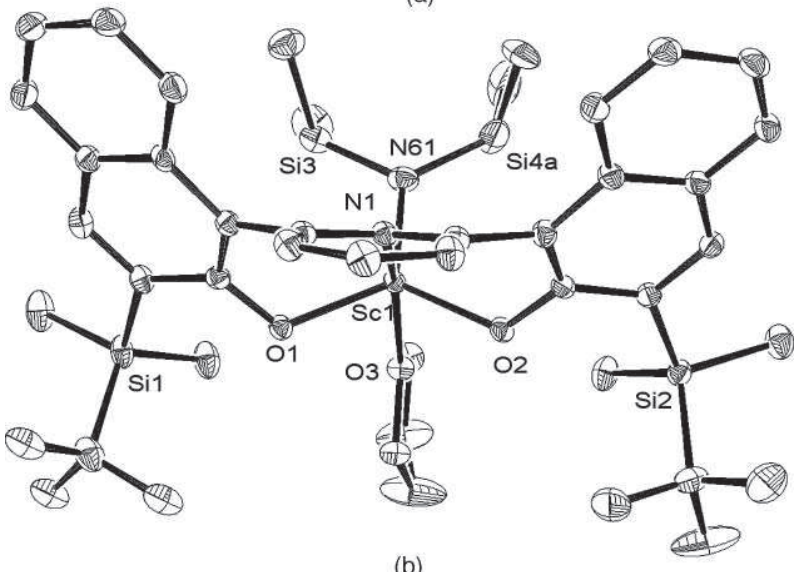

(b)

Fig. 3 ORTEP drawings of the structure of $\left\{\mathrm{ONO}^{\text {SitBuMe2 }}\right\}$ Sc$\left[\mathrm{N}\left(\mathrm{SiHMe}_{2}\right)_{2}\right](\mathrm{THF}) \quad$ (4) $\quad(50 \%$ ellipsoid probability; $\mathrm{H}$ atoms are omitted for clarity). Selected bond lengths ( $\AA$ ) and angles (deg.): $\mathrm{Sc}(1)-\mathrm{O}(1), 2.0218(15) ; \mathrm{Sc}(1)-\mathrm{O}(2), 2.0067(15) ; \mathrm{Sc}(1)-\mathrm{O}(3), 2.1852(16)$; $\mathrm{Sc}(1)-\mathrm{N}(1), \quad 2.3094(18) ; \quad \mathrm{Sc}(1)-\mathrm{N}(61), \quad 2.052(2) ; \quad \mathrm{O}(2)-\mathrm{Sc}(1)-\mathrm{O}(1)$, 125.51(6); $\mathrm{O}(2)-\mathrm{Sc}(1)-\mathrm{N}(61), \quad 116.21(7) ; \mathrm{O}(1)-\mathrm{Sc}(1)-\mathrm{N}(61), \quad 118.23(7) ;$ $\mathrm{O}(2)-\mathrm{Sc}(1)-\mathrm{O}(3), 87.13(6) ; \mathrm{O}(1)-\mathrm{Sc}(1)-\mathrm{O}(3), 86.44(6) ; \mathrm{N}(61)-\mathrm{Sc}(1)-\mathrm{O}(3)$, 99.33(7); $\quad \mathrm{O}(2)-\mathrm{Sc}(1)-\mathrm{N}(1), \quad 82.22(6) ; \quad \mathrm{O}(1)-\mathrm{Sc}(1)-\mathrm{N}(1), \quad 82.91(6) ;$ $\mathrm{N}(61)-\mathrm{Sc}(1)-\mathrm{N}(1), 104.12(7) ; \mathrm{O}(3)-\mathrm{Sc}(1)-\mathrm{N}(1), 156.54(6)$.

size of the metal center ${ }^{18}$ or its oxidation state. The coordination number of the metal center is another obvious parameter, the ligand adapting its binding mode upon the space available in the coordination sphere.

Overall, the $\mathrm{M}-\mathrm{O}$ and $\mathrm{M}-\mathrm{Z}$ bond distances in complexes $\mathbf{3}-\mathbf{5}$, $\mathbf{7}$, and $\mathbf{9}$ are unexceptional and compare well with those observed in related group 3 metal complexes supported by phenolate-donor type ligands $\mathrm{s}^{7,20}$ or analogous bis(trifluoromethyl)alkoxide-donor type ligands. ${ }^{21}$ Variations in $\mathrm{M}-\mathrm{O}$ and $\mathrm{M}-\mathrm{Z}$ bond distances within this series of complexes essentially reflect the difference in ionic radius between Sc, $\mathrm{Y}$ and La centers. ${ }^{18}$ Not enough data are available to allow for a thorough study of the effect of changing the silyl substituent and/or the donor linker. Yet, comparison between 3 and 9 shows shorter (by $c a$. $0.03-0.07 \AA$ ) $\mathrm{M}-\mathrm{O}(\mathrm{THF})$ and $\mathrm{M}-$ $\mathrm{N}\left(\mathrm{SiHMe}_{2}\right)$ bonds for the bis(naphtholate)thiophene system. This observation indicates a more electrophilic metal center in $\mathbf{9}$ than in 3 , possibly due to the weaker interaction of the metal center with the sulfur compared to the nitrogen donor. ${ }^{3 \mathrm{f}}$
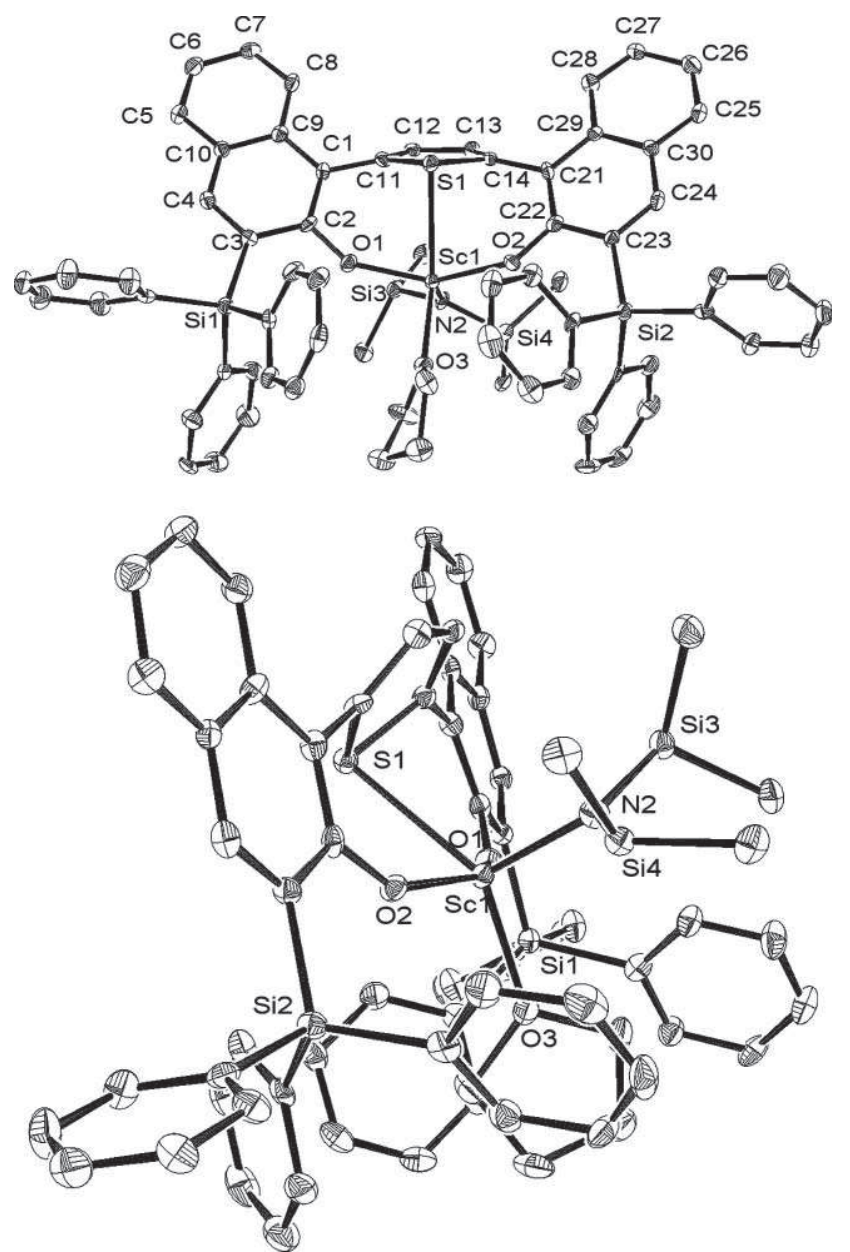

Fig. 4 ORTEP drawings of the structure of $\left\{\mathrm{OSO}^{\mathrm{SiPh} 3}\right\} \mathrm{Y}$ $\left[\mathrm{N}\left(\mathrm{SiHMe}_{2}\right)_{2}\right](\mathrm{THF}) \quad$ (7) $(50 \%$ ellipsoid probability; $\mathrm{H}$ atoms are omitted for clarity). Selected bond lengths ( $\AA$ ) and angles (deg.): $\mathrm{S}(1)-\mathrm{Sc}(1), \quad 2.7758(14) ; \quad \mathrm{Sc}(1)-\mathrm{O}(1), \quad 1.997(3) ; \quad \mathrm{Sc}(1)-\mathrm{O}(2), \quad 2.008(3)$; $\mathrm{Sc}(1)-\mathrm{O}(3), 2.124(3) ; \mathrm{Sc}(1)-\mathrm{N}(2), 2.027(4) ; \mathrm{O}(1)-\mathrm{Sc}(1)-\mathrm{O}(2), 143.37(13)$; $\mathrm{O}(1)-\mathrm{Sc}(1)-\mathrm{N}(2), \quad 106.27(15) ; \quad \mathrm{O}(2)-\mathrm{Sc}(1)-\mathrm{N}(2), \quad 105.54(15) ; \quad \mathrm{O}(1)$ $\mathrm{Sc}(1)-\mathrm{O}(3), \quad 93.18(13) ; \quad \mathrm{O}(2)-\mathrm{Sc}(1)-\mathrm{O}(3), \quad 98.04(13) ; \quad \mathrm{N}(2)-\mathrm{Sc}(1)-\mathrm{O}(3)$, 101.18(14); $\quad \mathrm{O}(1)-\mathrm{Sc}(1)-\mathrm{S}(1), \quad 76.03(9) ; \quad \mathrm{O}(2)-\mathrm{Sc}(1)-\mathrm{S}(1), \quad 74.91(9) ;$ $\mathrm{N}(2)-\mathrm{Sc}(1)-\mathrm{S}(1), 113.66(12) ; \mathrm{O}(3)-\mathrm{Sc}(1)-\mathrm{S}(1), 145.12(10)$.

Upon attempting to grow single crystals of amide compound 3 , small amounts of crystals differently shaped from the main products were isolated. Though the quality of these crystals was always poor (see Table 1), X-ray diffraction revealed these crystals to be the corresponding hydroxo complex $\mathbf{1 0}$, arising from adventitious hydrolysis (Scheme 4). As illustrated in Fig. 5, this compound

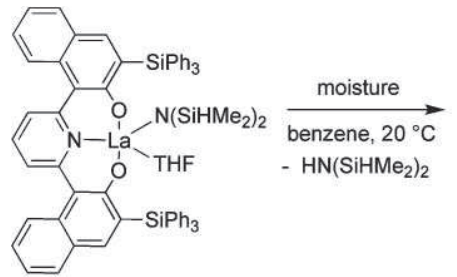

(3)

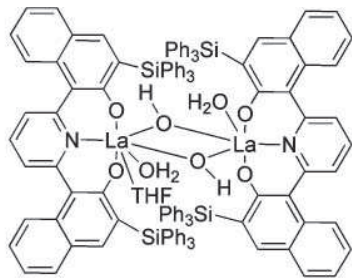

(10)
Scheme 4 


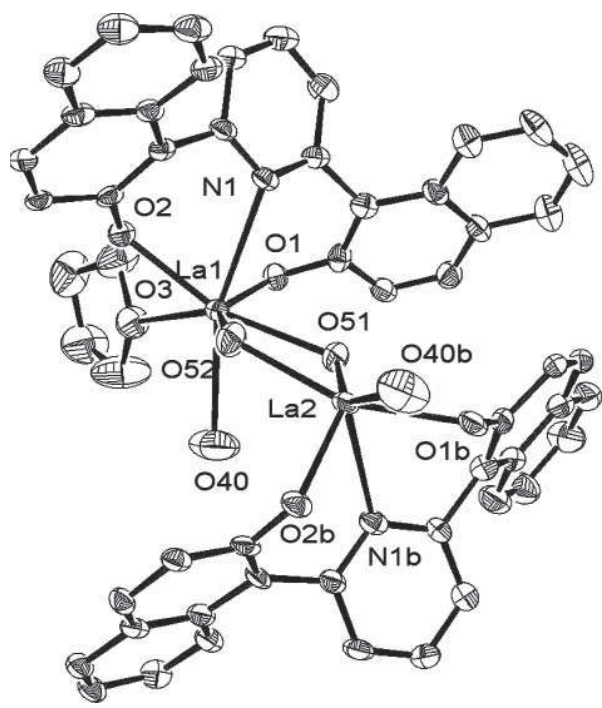

Fig. 5 ORTEP drawing of the structure of $\left[\left\{\mathrm{ONO}^{\mathrm{Siph} 3}\right\} \mathrm{La}-\right.$ $\left.(\mathrm{THF})\left(\mathrm{H}_{2} \mathrm{O}\right)(\mu-\mathrm{OH})_{2} \mathrm{La}\left(\mathrm{H}_{2} \mathrm{O}\right)\left\{\mathrm{ONO}^{\mathrm{Siph} 3}\right\}\right] \quad$ (10) $\quad(50 \% \quad$ ellipsoid probability; $\mathrm{H}$ atoms and $\mathrm{SiPh}_{3}$ groups are omitted for clarity). Selected bond lengths ( $\AA$ ) and angles (deg.): $\mathrm{La}(1)-\mathrm{O}(1), 2.327(4)$; $\mathrm{La}(1)-\mathrm{O}(2), 2.368(4) ; \quad \mathrm{La}(1)-\mathrm{O}(51), 2.489(4) ; \quad \mathrm{La}(1)-\mathrm{O}(52), 2.450(5)$; $\mathrm{La}(1)-\mathrm{O}(40), \quad 2.663(5) ; \quad \mathrm{La}(1)-\mathrm{O}(3), \quad 2.671(4) ; \quad \mathrm{La}(1)-\mathrm{N}(1), \quad 2.718(4) ;$ $\mathrm{La}(2)-\mathrm{O}(2 \mathrm{~B}), 2.352(3) ; \mathrm{La}(2)-\mathrm{O}(1 \mathrm{~B}), 2.362(4) ; \mathrm{La}(2)-\mathrm{O}(51), 2.383(4) ;$ $\mathrm{La}(2)-\mathrm{O}(52), 2.430(4) ; \mathrm{La}(2)-\mathrm{O}(40 \mathrm{~B}), 2.699(6) ; \mathrm{La}(2)-\mathrm{N}(1 \mathrm{~B}), 2.706(5)$; $\mathrm{O}(1)-\mathrm{La}(1)-\mathrm{O}(2), 108.46(14) ; \mathrm{O}(1)-\mathrm{La}(1)-\mathrm{O}(52), 143.63(13) ; \mathrm{O}(2)-\mathrm{La}(1)-$ $\mathrm{O}(52), \quad 94.92(14) ; \quad \mathrm{O}(1)-\mathrm{La}(1)-\mathrm{O}(51), \quad 81.01(14) ; \quad \mathrm{O}(2)-\mathrm{La}(1)-\mathrm{O}(51)$, 152.83(14); O(52)-La(1)-O(51), 66.51(15); O(1)-La(1)-O(40), 99.18(17); $\mathrm{O}(2)-\mathrm{La}(1)-\mathrm{O}(40), \quad 127.97(18) ; \mathrm{O}(52)-\mathrm{La}(1)-\mathrm{O}(40), 86.97(19) ; \mathrm{O}(51)$ $\mathrm{La}(1)-\mathrm{O}(40), 72.95(19) ; \mathrm{O}(1)-\mathrm{La}(1)-\mathrm{O}(3), 73.34(15) ; \mathrm{O}(2)-\mathrm{La}(1)-\mathrm{O}(3)$, 70.67(14); $\quad \mathrm{O}(52)-\mathrm{La}(1)-\mathrm{O}(3), \quad 142.28(15) ; \quad \mathrm{O}(51)-\mathrm{La}(1)-\mathrm{O}(3)$, 136.05(15); $\mathrm{O}(40)-\mathrm{La}(1)-\mathrm{O}(3), \quad 76.6(2) ; \quad \mathrm{O}(1)-\mathrm{La}(1)-\mathrm{N}(1), \quad 72.85(14) ;$ $\mathrm{O}(2)-\mathrm{La}(1)-\mathrm{N}(1), 70.31(14) ; \mathrm{O}(52)-\mathrm{La}(1)-\mathrm{N}(1), 90.20(15) ; \mathrm{O}(51)-\mathrm{La}(1)-$ $\mathrm{N}(1), \quad 89.32(14) ; \quad \mathrm{O}(40)-\mathrm{La}(1)-\mathrm{N}(1), \quad 161.67(19) ; \quad \mathrm{O}(3)-\mathrm{La}(1)-\mathrm{N}(1)$, $115.30(14)$

adopts in the solid state a dimeric structure with $\mu$-bridging hydroxy groups. In addition to the latter hydroxy groups, both La centers are coordinated by the tridentate $\left\{\mathrm{OZO}^{\text {Siph }}\right\}^{2-}$ ligand and one water molecule. One La center is thus six-coordinate, whereas the second one is seven-coordinate due to the presence of an additional coordinated THF molecule. The $\mathrm{La}-\mathrm{O}$ bond distances (2.383(4)-2.489(4) ̊) and O-La-O angles (66.5(1)$\left.68.5(1)^{\circ}\right)$ involving the bridging hydroxy groups $(\mathrm{O}(51,52))$ are comparable to those observed in the other rare examples reported of dimeric hydroxy-bridged La complexes (2.385-2.421 $\AA$ and $63.05-67.92^{\circ}$, respectively). ${ }^{22}$ Both $\left\{\mathrm{OZO}^{\mathrm{SiPh} 3}\right\}^{2-}$ ligand units are coordinated with the naphtholate rings in a $C_{\mathrm{s}}$ fashion with quite similar twist angles [i.e., the dihedral angle between the $\mathrm{M}-\mathrm{O}$ bonds and the plane of the pyridine] of 55.0, 55.1, 55.8 and $56.3^{\circ}$.
These twist angle values fall in the middle of the range observed for the parent complex 3 (49.2 and 63.3 ${ }^{\circ}$, vide supra).

\section{Preliminary studies on ring-opening polymerization of rac-Lactide

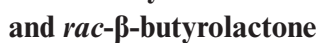

Group 3 metals and lanthanide complexes modified by ancillary ligands have received much attention in recent years for the controlled ring-opening polymerization (ROP) of cyclic esters such as lactide (LA) and, to a much lesser extent, $\beta$-butyrolactone (BBL). ${ }^{6,7,13,17}$ Activity $\left(\mathrm{mol}_{\text {monomer }} / \mathrm{mol}_{\text {metal }} \cdot \mathrm{h}\right)$, productivity ( $\left.\mathrm{mol}_{\text {monomer }} / \mathrm{mol}_{\text {metal }}\right)$, degree of control/"livingness", and stereoselectivity in the case of chiral monomers, depend crucially on ancillary ligands that define the sterics and electronics around the active metal center. Among the many systems investigated so far, a few of them have shown really valuable performances. This is notably the case of some group 3 metal complexes supported by triand tetradentate bis(phenolate) ligands which have been shown to induce significant heterotacticity and syndiotacticity in the ROP of $r a c$-LA and $r a c-\beta$-BBL, respectively. ${ }^{7}$ We were therefore interested in evaluating the catalytic performances of the new compounds 1-9 that possess a potentially active nucleophilic amido group for initiation of the ROP process and original ligand platforms.

The ability of the $\left\{\mathrm{OZO}^{\mathrm{SiR} 3}\right\} \mathrm{Ln}\left[\mathrm{N}\left(\mathrm{SiHMe}_{2}\right)_{2}\right](\mathrm{THF})$ complexes to promote the ROP of $r a c$-LA was first examined (Scheme 5) ${ }^{23}$ Representative results are summarized in Table 3. All complexes proved to be active at room temperature, enabling the conversion of 100-500 equiv of rac-LA within a few hours at most. The reactions proceeded significantly faster in toluene than in THF (compare entries 2/3, 4/9, 8/11, 16/17). This observation can probably be accounted for by the competing role of THF $v$ s rac-LA for coordination onto the metal center. All the PLAs formed under those conditions had unimodal, although broadened molecular distributions $\left(M_{\mathrm{w}} / M_{\mathrm{n}}=1.32-1.90\right)$ and experimental molecular weights (determined by SEC and corrected by a factor of 0.58 , due to the use of PS standards) $)^{24,25}$ quite close to the values calculated on the assumption of the growth of one macromolecular chain per metal. ${ }^{26}$ For a given experiment, monitoring showed that the molecular weight increases with conversion in a perfectly linear relationship (entries 4-5, 6-8, 12-13) (Fig. 6). Also, increasing the rac-LA loading from 100 to 500 equiv led to proportionally higher molecular weights PLAs (at high conversion) (see, e.g., entries 9/11). These data illustrate the overall good degree of control over the polymerization provided by the $\left\{\mathrm{OZO}^{\mathrm{SiR} 3}\right\} \mathrm{Ln}\left[\mathrm{N}\left(\mathrm{SiHMe}_{2}\right)_{2}\right](\mathrm{THF})$ systems.

Interestingly, we observed that the ROP of 500 equiv of $\mathrm{rac}$-LA could be performed using 5 equiv of $i \operatorname{PrOH}(v s \mathbf{3})$, leading to a PLA with accordingly decreased molecular weight (compare entries 10-13). This experiment corresponds to a so-called "immortal" polymerization in which the added alcohol acts as a transfer agent. ${ }^{7 e, 27}$ Dormant hydroxy-end-capped polymer chains exchange

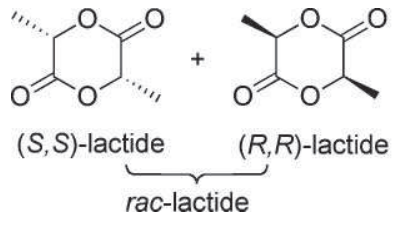

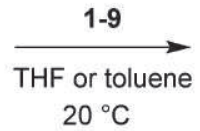

$20^{\circ} \mathrm{C}$

Scheme 5

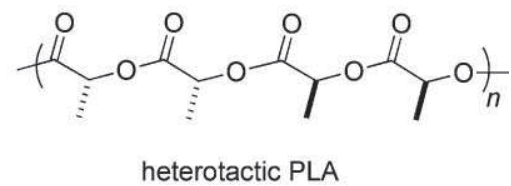

heterotactic PLA 
Table 3 Ring-opening polymerization of racemic lactide promoted by $\left\{\mathrm{OZO}^{\mathrm{SiR} 3}\right\} \mathrm{Ln}\left[\mathrm{N}\left(\mathrm{SiHMe}_{2}\right)_{2}\right](\mathrm{THF})$ complexes $^{a}$

\begin{tabular}{|c|c|c|c|c|c|c|c|c|c|}
\hline Entry & Comp. & {$[\mathrm{LA}] /[\mathrm{Ln}]$} & Solvent & Time $^{b} / \min$ & Conv. ${ }^{c}(\%)$ & $M_{\mathrm{n}, \mathrm{calc}}{ }^{d} / 10^{3} \mathrm{~g} \mathrm{~mol}^{-1}$ & $M_{\mathrm{n}, \exp } e / 10^{3} \mathrm{~g} \mathrm{~mol}^{-1}$ & $M_{\mathrm{w}} / M_{\mathrm{n}}^{e}$ & $P_{\mathrm{r}}^{f}$ \\
\hline 1 & 1 & 100 & THF & 700 & 100 & 14.4 & 16.2 & 1.55 & 0.65 \\
\hline 2 & 2 & 100 & THF & 60 & 71 & 10.2 & 8.9 & 1.32 & 0.90 \\
\hline 4 & 3 & 100 & THF & 40 & 87 & 12.5 & 12.7 & 1.43 & nd \\
\hline 5 & 3 & 100 & $\mathrm{THF}$ & 60 & 96 & 13.8 & 13.1 & 1.52 & 0.88 \\
\hline 6 & 3 & 500 & $\mathrm{THF}$ & 30 & 25 & 18.0 & 23.1 & 1.39 & nd \\
\hline 7 & 3 & 500 & $\mathrm{THF}$ & 60 & 42 & 30.3 & 38.2 & 1.55 & 0.87 \\
\hline 8 & 3 & 500 & THF & 360 & 74 & 53.3 & 49.8 & 1.90 & nd \\
\hline 9 & 3 & 100 & toluene & 2 & 100 & 14.4 & 17.5 & 1.68 & 0.68 \\
\hline 10 & 3 & 500 & toluene & 30 & 41 & 29.5 & 34.2 & 1.51 & nd \\
\hline 11 & 3 & 500 & toluene & 60 & 88 & 63.4 & 51.1 & 1.74 & nd \\
\hline $12^{g}$ & 3 & 500 & toluene & 30 & 85 & $12.3^{g}$ & $10.4^{g}$ & 1.36 & nd \\
\hline $13^{g}$ & 3 & 500 & toluene & 60 & 94 & $13.5^{g}$ & $12.7^{g}$ & 1.52 & nd \\
\hline 14 & 4 & 100 & $\mathrm{THF}$ & 700 & 100 & 14.4 & 17.1 & 1.61 & 0.93 \\
\hline 15 & 5 & 100 & $\mathrm{THF}$ & 700 & 100 & 14.4 & 17.3 & 1.52 & 0.84 \\
\hline 16 & $6^{h}$ & 100 & THF & 360 & 81 & 11.7 & 14.1 & 1.43 & 0.50 \\
\hline 18 & 7 & 100 & THF & 700 & 100 & 14.4 & 13.1 & 1.42 & 0.66 \\
\hline 19 & $8^{h}$ & 100 & $\mathrm{THF}$ & 700 & 100 & 14.4 & 14.0 & 1.82 & 0.68 \\
\hline 20 & $8^{h}$ & 100 & toluene & 700 & 100 & 14.4 & 11.2 & 1.47 & 0.50 \\
\hline 21 & 9 & 100 & THF & 700 & 100 & 14.4 & 11.6 & 1.51 & 0.75 \\
\hline 22 & 9 & 100 & toluene & 700 & 100 & 14.4 & 12.2 & 1.65 & 0.50 \\
\hline
\end{tabular}

${ }^{a}$ General conditions: $[\mathrm{rac}-\mathrm{LA}]=1.0 \mathrm{~mol} \mathrm{~L}-1, T=20^{\circ} \mathrm{C} .{ }^{b}$ Reactions times were not necessarily optimized. ${ }^{c}$ Conversion of lactide as determined by ${ }^{1} \mathrm{H}$ NMR on the crude reaction mixture. ${ }^{d} M_{\mathrm{n}}$ values calculated considering one polymer chain per metal-center from the relation: $M_{\mathrm{n}, \text { calc }}=\mathrm{conv} \times[\mathrm{LA}] /[\mathrm{Ln}] \times$ 144. ${ }^{e}$ Experimental $M_{\mathrm{n}}$ and $M_{\mathrm{w}} / M_{\mathrm{n}}$ values determined by GPC in THF $v s$. PS standards and corrected with 0.58 factor. ${ }^{f} P_{\mathrm{r}}$ is the probability of racemic linkage, as determined by ${ }^{1} \mathrm{H}$ NMR homodecoupling experiments. ${ }^{g}$ Polymerizations carried out in the presence of 5 equiv of $i \operatorname{PrOH} v s$. Ln. ${ }^{h}$ The complex was preliminary prepared from the in situ reaction of the pro-ligand and tris(amido) precursor.

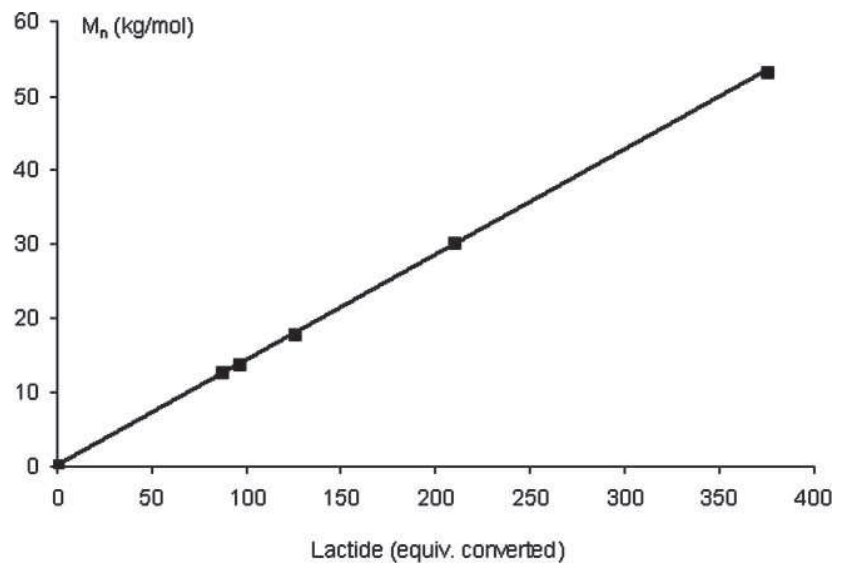

Fig. 6 Relationship between $M_{\mathrm{n}}$ of PLAs and conversion of rac-LA (Table 3, entries 4-5, 6-8).

with the active alkoxy-type polymer chain coordinated onto Ln, enabling the growth of more (i.e., 5) than one polymer chain per metal center. The polydispersity, at least similar to that observed using no $i \mathrm{PrOH}$, and the good match between experimental and calculated molecular weights establish that this transfer reaction (exchange between dormant and active polymer chains) proceeds significantly faster than propagation. ${ }^{7 e, 27}$ Analysis by ${ }^{1} \mathrm{H}$ NMR spectroscopy in $\mathrm{CDCl}_{3}$ of the low molecular weight PLAs obtained under such conditions showed clearly the existence of $\mathrm{HOCH}\left(\mathrm{CH}_{3}\right) \mathrm{CO}$ - (broadened quartet at $\delta 4.35 \mathrm{ppm}$ ) and $\mathrm{C}(\mathrm{O}) \mathrm{OCH}\left(\mathrm{CH}_{3}\right)_{2}$ (doublet at $\delta 1.25 \mathrm{ppm}$ for the methyl groups; the resonance for the $\mathrm{OCHMe}$ at $\delta c a .5 .1 \mathrm{ppm}$ mostly overlaps with those of PLA) end-groups, thus supporting the transfer process. $^{7 \mathrm{e}, 25}$
Most interestingly, homo-decoupled ${ }^{1} \mathrm{H}$ NMR spectroscopy showed that some of the PLAs formed with these systems had a significantly heterotactic-enriched microstructure. The probability of racemic linkage $\left(P_{\mathrm{r}}\right)$ ranged from 0.50 (atactic) up to 0.93 . As we observed with tetradentate bis(phenolato)-lanthanide systems, ${ }^{7 \mathrm{~b}-\mathrm{e}}$ the stereoselectivity strongly depended on the nature of the solvent: almost all the PLAs produced in toluene had an atactic microstructure whereas those obtained in THF were almost always heterotactic. The degree of heterotacticity was also quite different among the series of compounds 1-9, and appears to be affected by the nature of the metal center (Sc, Y, La), the central linker in the ligand framework (pyridine, thiophene), and the ortho-silyl substituent $\left(\mathrm{SiPh}_{3}, \mathrm{SiMe}_{2} t \mathrm{Bu}\right)$ as well. The bis(naphtholate)-thiophene framework is less efficient than that based on 2,6-pyridine; one can speculate that the [anticipated] weaker interaction of the soft $\mathrm{S}$ (as compared to the harder $\mathrm{N}$ ) atom induces a larger flexibility of the ligand and, as a result, a less sterically rigid coordination sphere around the active metal center. Within the series of $\left\{\mathrm{ONO}^{\mathrm{SiMe} 2 t \mathrm{Bu}}\right\}$-Ln complexes 4-6, the tacticity decreases with increasing ionic radius $^{18}$ (metal, $P_{\mathrm{r}}$ : Sc, 0.93; Y, $0.84 ; \mathrm{La}, 0.50)$. The same trend was observed with tetradentate bis(phenolato)-lanthanide systems, ${ }^{7 b-e}$ and was proposed to reflect a better contribution of sterically constrained metal centers on the chain-end stereocontrol. ${ }^{28}$ The aforementioned "ionic radius/heterotacticity" trend is, however, not observed within the series of $\left\{\mathrm{ONO}^{\mathrm{SiPh} 3}\right\}$-Ln complexes 1-3, since the smaller Sc led to a modest $P_{\mathrm{r}}$ value of 0.65 whereas the small $\mathrm{Y}$ and large $\mathrm{La}$ afforded about the same high heterotacticity $\left(P_{\mathrm{r}}=0.88-0.90\right)$.

The less reactive rac-BBL could also be polymerized to afford syndiotactic-enriched poly(3-hydroxybutyrate)s (PHBs) (Scheme 6). Representative results are summarized in Table 4. 
Table 4 Ring-opening polymerization of racemic $\beta$-butyrolactone promoted by $\left\{\mathrm{OZO}^{\mathrm{SiR} 3}\right\} \mathrm{Ln}\left[\mathrm{N}(\mathrm{SiHMe})_{2}\right](\mathrm{THF}) \operatorname{complexes}^{a}$

\begin{tabular}{|c|c|c|c|c|c|c|c|c|c|}
\hline Entry & Comp. & {$[\mathrm{BBL}] /[\mathrm{Ln}]$} & Solvent & Time $^{b} / \min$ & Conv. ${ }^{c}(\%)$ & $M_{\mathrm{n}, \text { calc }}{ }^{d} / 10^{3} \mathrm{~g} \mathrm{~mol}^{-1}$ & $M_{\mathrm{n}, \exp }{ }^{e} / 10^{3} \mathrm{~g} \mathrm{~mol}^{-1}$ & $M_{\mathrm{w}} / M_{\mathrm{n}}{ }^{e}$ & $P_{\mathrm{r}}^{f}$ \\
\hline $1^{g}$ & 1 & 100 & toluene & 1000 & 30 & 2.2 & 5.9 & 1.69 & 0.48 \\
\hline $2^{g, h}$ & 1 & 100 & toluene & 1000 & 62 & 5.3 & 7.1 & 1.32 & 0.48 \\
\hline 3 & 2 & 100 & toluene & 300 & 100 & 8.6 & 40.7 & 1.12 & 0.76 \\
\hline 4 & 2 & 300 & THF & 700 & 30 & 7.7 & 18.4 & 1.41 & 0.53 \\
\hline 5 & 2 & 100 & THF & 300 & 73 & 6.3 & 31.3 & 1.17 & 0.57 \\
\hline 6 & 2 & 300 & toluene & 700 & 70 & 18.1 & 20.3 & 1.29 & 0.78 \\
\hline $7^{g, h}$ & 2 & 100 & toluene & 30 & 100 & 8.6 & 17.8 & 1.32 & 0.87 \\
\hline 8 & 3 & 100 & THF & 100 & 80 & 6.9 & 11.1 & 1.25 & 0.53 \\
\hline 9 & 3 & 100 & toluene & 2 & 24 & 2.1 & 2.6 & 1.12 & 0.86 \\
\hline 10 & 3 & 100 & toluene & 15 & 62 & 5.3 & 7.0 & 1.38 & nd \\
\hline $11^{g, h}$ & 7 & 100 & toluene & 1000 & 40 & 3.4 & 3.2 & 1.45 & 0.60 \\
\hline 12 & 8 & 100 & THF & 1000 & 20 & 5.2 & 14.2 & 1.35 & 0.52 \\
\hline 13 & 8 & 100 & toluene & 1000 & 30 & 7.7 & 11.0 & 1.22 & 0.67 \\
\hline 14 & 9 & 300 & THF & 1000 & 100 & 25.8 & 23.5 & 1.35 & 0.46 \\
\hline 15 & 9 & 300 & toluene & 360 & 92 & 23.7 & 18.6 & 1.38 & 0.55 \\
\hline
\end{tabular}

${ }^{a}$ General conditions unless otherwise stated: $[\mathrm{rac}-\mathrm{BBL}]=3.0 \mathrm{~mol} \mathrm{~L}-1, T=20{ }^{\circ} \mathrm{C} .{ }^{b}$ Reactions times were not necessarily optimized. ${ }^{c}$ Conversion of lactide as determined by ${ }^{1} \mathrm{H}$ NMR on the crude reaction mixture. ${ }^{d} M_{\mathrm{n}}$ values calculated considering one polymer chain per metal-center from the relation: $M_{\mathrm{n}, \text { calc }}=\operatorname{conv} \times[\mathrm{BBL}] /[\mathrm{Ln}] \times 74 .{ }^{e}$ Experimental $M_{\mathrm{n}}$ (uncorrected) and $M_{\mathrm{w}} / M_{\mathrm{n}}$ values determined by GPC in THF $v s$. PS standards. ${ }^{f} P_{\mathrm{r}}$ is the probability of racemic linkage, as determined by ${ }^{13} \mathrm{C}$ NMR. ${ }^{g}$ Reaction carried out at $50{ }^{\circ} \mathrm{C} .{ }^{h}$ Polymerizations carried out in the presence of 1 equiv of $i \operatorname{PrOH} v s$. Ln.
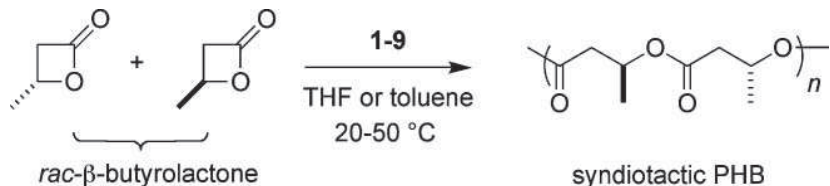

syndiotactic PHB

Scheme 6

At first, it must be noted that compounds 4-6 did not show any activity under the conditions investigated (THF, toluene, $20-50{ }^{\circ} \mathrm{C}$ ). Apparently, the inertness of this series of complexes seems to arise from the presence of $\mathrm{SiMe}_{2} t \mathrm{Bu}$ ortho-substituents, although the exact reason still remains obscure. The $\left\{\mathrm{OZO}^{\mathrm{SiPh}}\right\}$ Ln compounds 1-3 and 7-8 are active in the ROP of rac-BBL at room temperature, but an increase of the reaction temperature to $50{ }^{\circ} \mathrm{C}$ did prove useful in some cases to reduce the reaction time. This was particularly the case for scandium complexes $\mathbf{1}$ and 7 , which are quite sluggish (entries $1,2,11$ ). In those cases, the addition of 1 equiv of $i \operatorname{PrOH}(v s \mathrm{Ln})$, to generate in situ the corresponding $\left\{\mathrm{OZO}^{\mathrm{SiPh} 3}\right\} \mathrm{Sc}$-isopropoxide species, ${ }^{7 \mathrm{~b}-\mathrm{d}}$ enabled faster reactions, suggesting a relatively slow initiation with amido precursors (compare entries 1/2). Lanthanum complexes 3 and 9 showed the highest reaction rates. Similarly to the ROP of rac$\mathrm{LA}$, the ROP of rac-BBL with these systems proceeded faster in toluene than in THF.

Most of the resulting PHBs had experimental molecular weights (determined by SEC, uncorrected) in the range 4.1-28.1 $10^{3} \mathrm{~g}$ $\mathrm{mol}^{-1}$, which are in good agreement with the theoretical values [calculated assuming the growth of one polymer chain per metal center]. ${ }^{29}$ Molecular weights larger than those calculated were observed in some cases (entries 3, 5, 7, 12), apparently when low $[\mathrm{rac}-\mathrm{BBL}] /[\mathrm{Ln}]$ ratios were used; exact reasons for these discrepancies remain unclear at this time but one may speculate that the initiation efficiency is low under such conditions. The molecular weight distributions were unimodal and somewhat narrower $\left(M_{\mathrm{w}} / M_{\mathrm{n}}=1.12-1.69\right)$ than those observed for PLAs, indicative of the controlled character of the polymerizations. Detailed ${ }^{13} \mathrm{C}$ NMR analysis ${ }^{7 \mathrm{f}}$ revealed that some PHBs had a significantly syndiotactic-enriched microstructure, with $P_{\mathrm{r}}$ values ${ }^{7 \mathrm{f}}$ ranging from 0.48 (i.e., atactic) up to 0.87 . As exemplified for complexes 2, $\mathbf{3}$ and $\mathbf{9}$, the use of toluene as solvent led always to higher stereoselectivities than with THF; i.e., the opposite trend than that observed for the ROP of rac-LA (vide supra) but a trend consistent with our previous observations in the ROP of rac-BBL using tetradentate bis(phenolate)-Ln systems. ${ }^{7 \mathrm{~d}, \mathrm{f}}$ In line with the results for the ROP of rac-LA, the bis(naphtholate)thiophene framework $\left\{\mathrm{OSO}^{\mathrm{Siph} 3}\right\}^{2-}$ led to lower stereoselectivities (7-9, $\left.P_{\mathrm{r}}=0.55-0.67\right)$ than that based on 2,6-pyridine $\left\{\mathrm{ONO}^{\mathrm{SiPh} 3}\right\}^{2-}$, especially the $\mathrm{Y}$ and La complexes $\left(\mathbf{2}, \mathbf{3}, P_{\mathrm{r}}=076-0.87\right.$ and 0.86 , respectively). The latter levels of syndiotacticity are just below those we achieved with tetradentate bis(phenolate)-Ln systems (the most stereoselective systems reported to date; $P_{\mathrm{r}}=$ up to $0.94),{ }^{\text {d,f } \mathrm{f}}$ and range among the highest reported thus far for the ROP of rac-BBL.

\section{Conclusions}

In conclusion, we have readily prepared in high yields a series of scandium, yttrium and lanthanum amido complexes supported by tridentate bis(ortho-silyl-substituted naphtholate)-donor ligands, via the reaction of the corresponding pro-ligand $\left\{\mathrm{OZO}^{\mathrm{SiR} 3}\right\} \mathrm{H}_{2}$ and $\mathrm{Ln}\left[\mathrm{N}\left(\mathrm{SiHMe}_{2}\right)_{2}\right]_{3}(\mathrm{THF})_{n}$ precursor. Those complexes all adopt a $C_{\mathrm{s}}$-symmetric ground state structure in the solid state, as observed for compounds 1-3 and 7-9, and in toluene solution as well.

Compounds 1-9 are single-site initiators for the ROP of rac-LA at $20^{\circ} \mathrm{C}$, affording PLAs with relatively narrow polydispersities and molecular weights in good agreement with calculated values. Atactic polymers are formed in toluene but, when carried out in THF, the polymerizations afforded heterotactic-enriched PLAs $\left(P_{\mathrm{r}}\right.$ up to 0.93$)$. Immortal polymerization, with good control over the number and molecular weight of polymer chains, can be performed upon addition of isopropanol as a transfer agent. Compounds 1-3 and 7-9, having $o-\mathrm{SiPh}_{3}$ substituents on the naphtholate rings, are also active for the ROP of $r a c-B B L$ at $20-50{ }^{\circ} \mathrm{C}$, to form syndiotactic-enriched PHBs ( $P_{\mathrm{r}}$ up to 0.87 ) when using toluene as the solvent, whereas essentially atactic 
polymers were obtained in THF. The degree of stereocontrol in those polymerizations of $r a c-\mathrm{LA}$ and $\mathrm{rac}-\mathrm{BBL}$ is significantly affected by the nature (and ionic radius) of the metal center (Sc, Y, La), the central linker in the ligand framework (pyridine, thiophene), and the ortho-silyl substituent $\left(\mathrm{SiPh}_{3}, \mathrm{SiMe}_{2} t \mathrm{Bu}\right)$. However, no clear trends for predicting a property have been identified thus far. The inactivity of complexes 4-6 in the ROP of rac-BBL, at least under the conditions investigated, strikes at the real influence of the ortho-silyl substituents installed on the naphtholate rings. Those first results suggest that improvements in terms of activity (and productivity as well, via immortal ROP), and stereoselectivity are accessible via further tuning of the substituents installed on the naphtholate rings.

\section{Experimental}

\section{General considerations}

All manipulations were carried out under purified argon using standard Schlenk techniques or in a glove box. Toluene and benzene were freshly distilled under argon from $\mathrm{Na}$ /benzophenone and were condensed under vacuum prior to use. Deuterated solvents ( $>99.5 \% \mathrm{D}$, Eurisotop) were freshly distilled or vacuum-transferred from $\mathrm{Na} / \mathrm{K}$ alloy under argon and degassed prior to use. Pro-ligands $\left\{\mathrm{OZO}^{\mathrm{R}}\right\} \mathrm{H}_{2}\left(Z=\mathrm{N}\right.$; $\mathrm{R}=\mathrm{SiPh}_{3}$, $\left.\mathrm{SiMe}_{2} t \mathrm{Bu} ; Z=\mathrm{S}, \mathrm{R}=\mathrm{SiPh}_{3}\right),{ }^{11} \mathrm{Y}\left(\mathrm{N}\left(\mathrm{SiHMe}_{2}\right)_{2}\right)_{3} \cdot(\mathrm{THF}),{ }^{14 \mathrm{a}}$ $\mathrm{La}\left(\mathrm{N}\left(\mathrm{SiHMe}_{2}\right)_{2}\right)_{3} \cdot(\mathrm{THF})_{2},{ }^{14 \mathrm{a}}$ and $\mathrm{Sc}\left(\mathrm{N}\left(\mathrm{SiHMe}_{2}\right)_{2}\right)_{3} \cdot(\mathrm{THF})^{14 \mathrm{a}}$ were synthesized according to the reported procedures. rac-LA (Aldrich) was recrystallized from dry methanol and toluene, and sublimed under vacuum at $50{ }^{\circ} \mathrm{C}$. rac-BBL (TCI) was freshly distilled from $\mathrm{CaH}_{2}$ under argon and degassed thoroughly by freeze-vacuum-thaw cycles.

NMR spectra of complexes were recorded in Teflon ${ }^{\mathrm{TM}}$-valved NMR tubes on Bruker AC-200, AC-300 and AM-500 spectrometers at $20{ }^{\circ} \mathrm{C}$ unless otherwise stated. ${ }^{1} \mathrm{H}$ and ${ }^{13} \mathrm{C}$ NMR chemical shifts (see Scheme 7) were determined using residual solvent resonances and are reported vs. $\mathrm{SiMe}_{4}$. Assignment of signals was made from $2 \mathrm{D}{ }^{1} \mathrm{H}^{-1} \mathrm{H}$ COSY and ${ }^{1} \mathrm{H}_{-}{ }^{13} \mathrm{C}$ HMQC and HMBC NMR experiments (see Scheme 5 for numbering of ligand hydrogens). ${ }^{19} \mathrm{~F}$ chemical shifts were determined by external reference to an aqueous solution of $\mathrm{NaBF}_{4}$. All coupling constants are given in Hertz. Elemental analyses $(\mathrm{C}, \mathrm{H}, \mathrm{N})$ were performed using a Flash EA1112 CHNS Thermo Electron apparatus and are the average of two independent determinations. Molecular weights of PLAs and PHBs were determined by size exclusion chromatography (SEC) at room temperature in THF on a Polymer Laboratories PL-GPC 50 plus apparatus (PLgel $5 \mu \mathrm{m}$ MIXED-

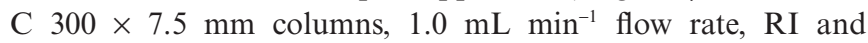
Dual angle LS (PL-LS 45/90) detectors). The number average

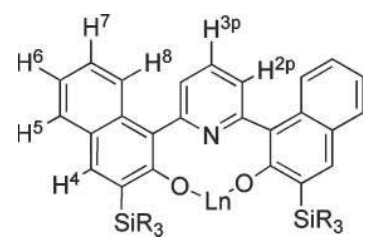

Scheme 7 Numbering scheme of 1,1-bis(naphtholate)-1', $1^{\prime}$-pyridine ligands. molecular masses $\left(M_{\mathrm{n}}\right)$ and polydispersity index $\left(M_{\mathrm{w}} / M_{\mathrm{n}}\right)$ of the polymers were calculated with reference to a universal calibration $v s$. polystyrene standards. $M_{\mathrm{n}}$ values of PLAs were corrected with a factor of 0.58 to account for the difference in hydrodynamic volumes of polystyrenes. ${ }^{24} M_{\mathrm{n}}$ values of PHBs are uncorrected. The microstructure of PLAs was determined by homodecoupling ${ }^{1} \mathrm{H}$ NMR spectroscopy at $20{ }^{\circ} \mathrm{C}$ in $\mathrm{CDCl}_{3}$ with a Bruker AM500 spectrometer. The microstructure of PHBs was determined by analysis of the carbonyl region of ${ }^{13} \mathrm{C}$ NMR spectra recorded at $25^{\circ} \mathrm{C}$ in $\mathrm{CDCl}_{3}$ on a Bruker Avance AM-500 spectrometer. ${ }^{3 \mathrm{~d}, \mathrm{f}}$

\section{$\left\{\mathrm{ONO}^{\mathrm{SiPh} 3}\right\} \mathbf{S c}\left[\mathbf{N}\left(\mathrm{SiHMe}_{2}\right)_{2}\right](\mathrm{THF})(1)$}

A Schlenk flask was charged with $\left\{\mathrm{ONO}^{\mathrm{SiPh} 3}\right\} \mathrm{H}_{2}(0.051 \mathrm{~g}$, $0.060 \mathrm{mmol})$ and $\mathrm{Sc}\left[\mathrm{N}\left(\mathrm{SiHMe}_{2}\right)_{2}\right]_{3}(\mathrm{THF})(0.030 \mathrm{~g}, 0.060 \mathrm{mmol})$, and benzene $(c a .5 \mathrm{~mL})$ was vacuum transferred in at $-78^{\circ} \mathrm{C}$. The reaction mixture was gently warmed to room temperature and stirred overnight. Filtration of the clear solution and evaporation of volatiles in vacuum left $\mathbf{1}$ as a pale yellow microcrystalline powder $(0.057 \mathrm{~g}, 84 \%) .{ }^{1} \mathrm{H}$ NMR $\left(500 \mathrm{MHz}\right.$, benzene- $\left.d_{6}, 298 \mathrm{~K}\right)$ : $\delta 8.20\left(\mathrm{~d},{ }^{3} \mathrm{~J}=8.5,2 \mathrm{H}\right.$, Haro), $8.16\left(\mathrm{~s}, 2 \mathrm{H}^{4}\right.$, Haro), 7.93-8.03 (m, 12H, Haro), 7.46 (m, 6H, Haro), 7.22-7.31 (m, 18H, Haro), $7.13\left(\mathrm{~d},{ }^{3} J=7.0,2 \mathrm{H}\right.$, Haro $), 6.91\left(\mathrm{t},{ }^{3} J=7.0,1 \mathrm{H}, \mathrm{H}^{3 \mathrm{p}}\right), 4.45$ (m, 2H, SiHMe), 2.96 (m, 4H, $\left.\alpha-\mathrm{CH}_{2}, \mathrm{THF}\right), 0.69$ (m, 4H, $\beta$ $\left.\mathrm{CH}_{2}, \mathrm{THF}\right),-0.12\left(\mathrm{~d},{ }^{3} \mathrm{~J}=2.1,12 \mathrm{H}, \mathrm{SiH} M e_{2}\right) .{ }^{13} \mathrm{C}\left\{{ }^{1} \mathrm{H}\right\} \mathrm{NMR}$ (125 MHz, benzene- $\left.d_{6}, 298 \mathrm{~K}\right): \delta 164.0,155.7,145.0,137.0,136.7$, 136.4, 136.0, 129.3, 128.7, 128.0, 127.3, 127.6, 127.1, 126.4, 124.0, 122.2, 117.6 (Caro), 70.1 ( $\left.\alpha-\mathrm{CH}_{2}, \mathrm{THF}\right), 24.2$ ( $\left.\beta-\mathrm{CH}_{2}, \mathrm{THF}\right), 2.5$ $\left(\mathrm{SiHMe}_{2}\right)$. Anal. calcd. for $\mathrm{C}_{69} \mathrm{H}_{65} \mathrm{~N}_{2} \mathrm{O}_{3} \mathrm{ScSi}_{4}: \mathrm{C}, 73.50 ; \mathrm{H}, 5.81 ; \mathrm{N}$, 2.48. Found: C, 73.1; H, 5.4; N, 2.4 .

\section{$\left\{\mathrm{ONO}^{\mathrm{SiPh}}\right\}$ Y $\left[\mathrm{N}\left(\mathrm{SiHMe}_{2}\right)_{2}\right](\mathrm{THF})(2)$}

This compound was prepared following the same procedure as that described above for $\mathbf{1}$, starting from $\left\{\mathrm{ONO}^{\mathrm{SiPh} 3}\right\} \mathrm{H}_{2}(0.079 \mathrm{~g}$, $0.090 \mathrm{mmol})$ and $\mathrm{Y}\left[\mathrm{N}\left(\mathrm{SiHMe}_{2}\right)_{2}\right]_{3}$ (THF) $(0.050 \mathrm{~g}, 0.090 \mathrm{mmol})$ in benzene $(5 \mathrm{~mL})$. Compound $\mathbf{2}$ was obtained as a pale yellow microcrystalline powder $(0.089 \mathrm{~g}, 84 \%) .{ }^{1} \mathrm{H}$ NMR $(500 \mathrm{MHz}$, benzene- $\left.d_{6}, 298 \mathrm{~K}\right): \delta 8.19\left(\mathrm{~s}, 2 \mathrm{H}, \mathrm{H}^{4}\right), 8.04\left(\mathrm{~d},{ }^{3} \mathrm{~J}=7.1,2 \mathrm{H}\right.$, $\left.\mathrm{H}^{5}\right)$, 7.96-8.00 (m, 12H, Haro), $7.47\left(\mathrm{~d},{ }^{3} J=7.1,2 \mathrm{H}, \mathrm{H}^{8}\right), 7.40$ $\left(\mathrm{t},{ }^{3} J=7.1,2 \mathrm{H}, \mathrm{H}^{7}\right), 7.36\left(\mathrm{~d},{ }^{3} J=7.7,2 \mathrm{H}, \mathrm{H}^{2 \mathrm{p}}\right), 7.23-7.27(\mathrm{~m}$, $18 \mathrm{H}$, Haro), $7.12\left(\mathrm{~d},{ }^{3} J=7.1,2 \mathrm{H}, \mathrm{H}^{6}\right), 6.94\left(\mathrm{t},{ }^{3} J=7.1,1 \mathrm{H}, \mathrm{H}^{3 \mathrm{p}}\right)$, 4.31 (sept, ${ }^{3} J=2.8,2 \mathrm{H}, \mathrm{SiHMe}$ ), 2.81 (br m, 4H, $\alpha-\mathrm{CH}_{2}$, THF), 0.86 (br m, $\left.4 \mathrm{H}, \beta-\mathrm{CH}_{2}, \mathrm{THF}\right),-0.11\left(\mathrm{~d},{ }^{3} J=3.0,12 \mathrm{H}, \mathrm{SiH} M e_{2}\right.$ ). ${ }^{13} \mathrm{C}\left\{{ }^{1} \mathrm{H}\right\}$ NMR $\left(125 \mathrm{MHz}\right.$, benzene- $\left.d_{6}, 298 \mathrm{~K}\right): \delta 163.2,156.7$, $144.8,136.9,136.7,136.6,129.2,128.4,128.3,128.1,128.0,127.5$, 127.4, 127.3, 123.7, 122.0, 117.4 (Caro), 69.1 ( $\alpha-\mathrm{CH}_{2}$, THF), 24.7 ( $\left.\beta-\mathrm{CH}_{2}, \mathrm{THF}\right), 2.5\left(\mathrm{SiHMe}_{2}\right)$. Anal. calcd. for $\mathrm{C}_{69} \mathrm{H}_{65} \mathrm{~N}_{2} \mathrm{O}_{3} \mathrm{Si}_{4} \mathrm{Y}: \mathrm{C}$, 70.74; H, 5.59; N, 2.39. Found: C, 70.2; H, 5.1; N, 2.4.

\section{$\left\{\mathrm{ONO}^{\mathrm{SiPh3}}\right\} \mathrm{La}\left[\mathrm{N}\left(\mathrm{SiHMe}_{2}\right)_{2}\right](\mathrm{THF})$ (3)}

This compound was prepared following the same procedure as that described above for $\mathbf{1}$, starting from $\left\{\mathrm{ONO}^{\mathrm{SiPh} 3}\right\} \mathrm{H}_{2}(0.100 \mathrm{~g}$, $0.110 \mathrm{mmol})$ and $\mathrm{La}\left[\mathrm{N}\left(\mathrm{SiHMe}_{2}\right)_{2}\right]_{3}(\mathrm{THF})_{2}(0.077 \mathrm{~g}, 0.11 \mathrm{mmol})$ in benzene $(5 \mathrm{~mL})$. Compound 3 was obtained as a pale yellow microcrystalline powder $(0.130 \mathrm{~g}, 91 \%)$. Crystals of 3 suitable for $\mathrm{X}$-ray diffraction analysis were prepared by prolonged crystallization from a concentrated benzene solution at room temperature. ${ }^{1} \mathrm{H}$ NMR $\left(500 \mathrm{MHz}\right.$, benzene- $\left.d_{6}, 298 \mathrm{~K}\right): \delta 8.24\left(\mathrm{~s}, 2 \mathrm{H}, \mathrm{H}^{4}\right)$, 8.03-7.94 (m, 14H, Haro), 7.50 (d, ${ }^{3} J=7.7,2 \mathrm{H}$, Haro), 7.39 (m, 
2H, Haro), 7.31 (d, $\left.{ }^{3} J=7.7,2 \mathrm{H}, \mathrm{H}^{\text {aro }}\right), 7.29-7.19$ (m, 18H, Haro), 7.17 (m, 2H, Haro), $6.98\left(\mathrm{t},{ }^{3} J=7.7,1 \mathrm{H}, \mathrm{H}^{3 \mathrm{p}}\right), 4.29$ (sept, ${ }^{3} J=$ 2.8, 2H, Si HMe), 3.07 (br m, 4H, $\alpha-\mathrm{CH}_{2}, \mathrm{THF}$ ), 1.07 (br m, 4H, $\left.\beta-\mathrm{CH}_{2}, \mathrm{THF}\right),-0.11\left(\mathrm{~d},{ }^{3} \mathrm{~J}=2.8,12 \mathrm{H}, \mathrm{SiHMe} e_{2}\right){ }^{13} \mathrm{C}\left\{{ }^{1} \mathrm{H}\right\} \mathrm{NMR}$ (125 MHz, benzene- $\left.d_{6}, 298 \mathrm{~K}\right): \delta 162.1,156.6,144.3,138.5,137.0$, $136.9,132.6,129.3,129.2,128.3,128.0,127.9,127.8,127.3,123.8$, 121.9, 118.3 (Caro), 68.3 ( $\alpha-\mathrm{CH}_{2}$, THF), 24.9 ( $\beta-\mathrm{CH}_{2}, \mathrm{THF}$ ), -2.5 $\left(\mathrm{SiHMe}_{2}\right)$. Anal. calcd. for $\mathrm{C}_{69} \mathrm{H}_{65} \mathrm{LaN}_{2} \mathrm{O}_{3} \mathrm{Si}_{4}: \mathrm{C}, 67.85 ; \mathrm{H}, 5.36 ; \mathrm{N}$, 2.29. Found: C, 67.3; H, 5.4; N, 2.3.

\section{$\left\{\mathrm{ONO}^{\mathrm{SitBuMe} 2}\right\} \mathrm{Sc}\left[\mathrm{N}\left(\mathrm{SiHMe}_{2}\right)_{2}\right](\mathrm{THF})(4)$}

This compound was prepared following the same procedure as that described above for $\mathbf{1}$, starting from $\left\{\mathrm{ONO}^{\mathrm{SitBuMe} 2}\right\} \mathrm{H}_{2}$ $(0.046 \mathrm{~g}, 0.090 \mathrm{mmol})$ and $\mathrm{Sc}\left[\mathrm{N}\left(\mathrm{SiHMe}_{2}\right)_{2}\right]_{3}(\mathrm{THF})(0.040 \mathrm{~g}$, $0.090 \mathrm{mmol})$ in benzene $(5 \mathrm{~mL})$. Compound $\mathbf{4}$ was obtained as a pale yellow microcrystalline material $(0.067 \mathrm{~g}, 72 \%)$. Crystals of 4 suitable for X-ray diffraction analysis were prepared by prolonged crystallization from a concentrated benzene solution at room temperature. ${ }^{1} \mathrm{H}$ NMR $\left(500 \mathrm{MHz}\right.$, benzene- $\left.d_{6}, 298 \mathrm{~K}\right): \delta$ $8.36\left(\mathrm{~s}, 2 \mathrm{H}^{4}\right), 8.01\left(\mathrm{br} \mathrm{d},{ }^{3} \mathrm{~J}=8.2,2 \mathrm{H}, \mathrm{H}^{5}\right), 7.86\left(\mathrm{br} \mathrm{d},{ }^{3} \mathrm{~J}=7.9,2 \mathrm{H}\right.$, $\left.\mathrm{H}^{8}\right), 7.39\left(\mathrm{brt},{ }^{3} J=7.9,2 \mathrm{H}, \mathrm{H}^{7}\right), 7.29\left(\mathrm{~m}, 4 \mathrm{H}, \mathrm{H}^{6+2 \mathrm{p}}\right), 6.92\left(\mathrm{br} \mathrm{t},{ }^{3} J=\right.$ 7.7, $1 \mathrm{H}, \mathrm{H}^{3 \mathrm{p}}$ ), 4.63 (br m, 2H, SiHMe), 4.49 (br m, 4H, $\alpha-\mathrm{CH}_{2}$, THF), 1.73 (br m, 4H, $\beta-\mathrm{CH}_{2}, \mathrm{THF}$ ), 1.27 (s, 18H, $\mathrm{SiMe}_{2} t B u$ ), 0.71 (s, 6H, SiMeMetBu), 0.68 (s, 6H, SiMeMetBu), -0.20 (br s, $\left.12 \mathrm{H}, \mathrm{SiH} M e_{2}\right) .{ }^{13} \mathrm{C}\left\{{ }^{1} \mathrm{H}\right\}$ NMR $\left(125 \mathrm{MHz}\right.$, benzene- $\left.d_{6}, 298 \mathrm{~K}\right): \delta$ 163.7, 140.6, 136.6, 135.4, 128.7, 128.3, 128.1, 128.0, 127.9, 126.97, 123.8, 122.2 (Caro), $71.3\left(\alpha-\mathrm{CH}_{2}, \mathrm{THF}\right), 27.6\left(\mathrm{C}\left(\mathrm{CH}_{3}\right)_{3}\right), 25.2(\beta-$ $\mathrm{CH}_{2}$, THF), $17.9\left(\mathrm{C}\left(\mathrm{CH}_{3}\right)_{3}\right), 2.8(\mathrm{SiMe} 2 \mathrm{Bu}), 2.2\left(\mathrm{SiHMe}_{2}\right)$. VT ${ }^{1} \mathrm{H}$ NMR: ${ }^{1} \mathrm{H}$ NMR $\left(500 \mathrm{MHz}\right.$, toluene- $d_{8}, 338 \mathrm{~K}$ ): $\delta 8.17$ (s, $\left.2 \mathrm{H}^{4}\right), 7.87\left(\right.$ br d, $\left.{ }^{3} J=8.3,2 \mathrm{H}^{5}\right), 7.70\left(\right.$ br d, $\left.{ }^{3} J=7.9,2 \mathrm{H}^{8}\right), 7.26(\mathrm{~m}$, $4 \mathrm{H}^{6+2 \mathrm{p}}$ ), 7.16 (br t, ${ }^{3} J=7.9,2 \mathrm{H}^{7}$ ), 7.05 (br m, $1 \mathrm{H}^{3 \mathrm{p}}$ ), 4.51 (br m, $2 \mathrm{H}$, $\mathrm{SiHMe}$ ), 4.34 (br m, 4H, $\alpha-\mathrm{CH}_{2}$, THF), 1.72 (br m, 4H, $\beta-\mathrm{CH}_{2}$, THF), 1.13 (s, 18H, SitBuMe $\mathrm{Me}_{2}, 0.58$ (s, 12H, SitBuMe $e_{2}$ ),-0.31 (s, $12 \mathrm{H}, \mathrm{SiHMe}$ ). ${ }^{1} \mathrm{H}$ NMR $\left(500 \mathrm{MHz}\right.$, toluene- $\left.d_{8}, 313 \mathrm{~K}\right): \delta 8.20(\mathrm{~s}$, $\left.2 \mathrm{H}^{4}\right), 7.88\left(\right.$ br d, $\left.{ }^{3} J=8.2,2 \mathrm{H}^{5}\right), 7.71\left(\right.$ br d, $\left.{ }^{3} J=7.9,2 \mathrm{H}^{8}\right), 7.27$ (br t, $\left.{ }^{3} J=7.9,2 \mathrm{H}^{7}\right), 7.22\left(\right.$ br d, ${ }^{3} J=7.7,2 \mathrm{H}^{2 \mathrm{p}}$ ), 7.17 (br t, ${ }^{3} J=$ $8.2,2 \mathrm{H}^{6}$ ), 6.98 (br t, ${ }^{3} J=7.7,1 \mathrm{H}^{3 \mathrm{p}}$ ), 4.50 (br m, $2 \mathrm{H}, \mathrm{Si} H \mathrm{Me}$ ), 4.33 (br m, 4H, $\alpha-\mathrm{CH}_{2}$, THF), 1.71 (br m, 4H, $\beta-\mathrm{CH}_{2}, \mathrm{THF}$ ), 1.51 (s, $18 \mathrm{H}, \mathrm{Si} t B u \mathrm{Me}_{2}$ ), 0.59 (s, 12H, Sit BuMe $e_{2}$ ), -0.32 (s, 12H, SiHMe $e_{2}$. ${ }^{1} \mathrm{H}$ NMR (500 MHz, toluene- $d_{8}, 298 \mathrm{~K}$ ): $\delta 8.21\left(\mathrm{~s}, 2 \mathrm{H}^{4}\right), 7.89(\mathrm{br}$ $\left.\mathrm{d},{ }^{3} J=8.3,2 \mathrm{H}^{5}\right), 7.72\left(\mathrm{br} \mathrm{d},{ }^{3} J=7.7,2 \mathrm{H}^{8}\right), 7.27$ (br t, ${ }^{3} J=7.7$, $\left.2 \mathrm{H}^{7}\right), 7.19\left(\mathrm{~m}, 4 \mathrm{H}^{6+2 \mathrm{p}}\right), 6.94\left(\right.$ br t $\left.,{ }^{3} J=7.9,1 \mathrm{H}^{3 \mathrm{p}}\right), 4.49($ br s, $2 \mathrm{H}$, $\mathrm{SiHMe}), 4.40$ (m, 4H, $\alpha-\mathrm{CH}_{2}$, THF), 1.75 (m, 4H, $\beta-\mathrm{CH}_{2}$, THF), 1.16 (s, 18H, SitBuMe $)_{2}, 0.16$ (br s, 12H, SitBuMe $),-0.30$ (br s, $12 \mathrm{H}, \mathrm{SiHMe} 2) .{ }^{1} \mathrm{H}$ NMR $\left(500 \mathrm{MHz}\right.$, toluene- $d_{8}, 273 \mathrm{~K}$ ): $\delta 8.24$ (s, $\left.2 \mathrm{H}^{4}\right), 7.90\left(\right.$ br d, $\left.{ }^{3} J=8.3,2 \mathrm{H}^{5}\right), 7.73\left(\right.$ br d, $\left.{ }^{3} J=7.7,2 \mathrm{H}^{8}\right), 7.29$ (br t, $\left.{ }^{3} J=7.7,2 \mathrm{H}^{7}\right), 7.20$ (br t, $\left.{ }^{3} J=8.3,2 \mathrm{H}^{6}\right), 7.17\left(\mathrm{~m}, 2 \mathrm{H}^{2 \mathrm{p}}\right.$ ), 6.86 (br t, ${ }^{3} \mathrm{~J}=7.7,1 \mathrm{H}^{3 \mathrm{p}}$ ), 4.48 (br m, $2 \mathrm{H}, \mathrm{SiHMe}+4 \mathrm{H}, \alpha-\mathrm{CH}_{2}$, THF), 1.78 (br m, 4H, $\beta-\mathrm{CH}_{2}, \mathrm{THF}$ ), 1.19 (s, 18H, SitBuMe ${ }_{2}$ ), 0.63 (s, 6H, SitBuMeMe), 0.59 (s, 6H, Si $t \mathrm{Bu} M e(\mathrm{Me}),-0.32$ (s, $12 \mathrm{H}, \mathrm{SiHMe}) .{ }^{1} \mathrm{H}$ NMR $\left(500 \mathrm{MHz}\right.$, toluene- $\left.d_{8}, 223 \mathrm{~K}\right): \delta 8.28(\mathrm{~s}$, $\left.2 \mathrm{H}^{4}\right), 7.93\left(\mathrm{~d},{ }^{3} J=8.6,2 \mathrm{H}^{5}\right), 7.75\left(\mathrm{~d},{ }^{3} J=8.6,2 \mathrm{H}^{8}\right), 7.80\left(\mathrm{~m}, 2 \mathrm{H}^{6}\right)$, $7.22\left(\mathrm{~m}, 2 \mathrm{H}^{7}\right), 7.11\left(\mathrm{~m}, 2 \mathrm{H}^{2 \mathrm{p}}\right), 6.74\left(\mathrm{t},{ }^{3} J=7.8,1 \mathrm{H}^{3 \mathrm{p}}\right), 4.52$ (sept, $\left.{ }^{3} J=3.0,2 \mathrm{H}, \mathrm{SiHMe}\right), 4.45$ (m, 4H, $\left.\alpha-\mathrm{CH}_{2}, \mathrm{THF}\right), 1.65$ (m, 4H, $\beta-\mathrm{CH}_{2}, \mathrm{THF}$ ), 1.22 (s, 18H, SitBuMe $\mathrm{Me}_{2}$, 0.65 (s, 6H, SitBuMeMe), 0.62 (s, 6H, SitBuMe Me), -0.30 (d, $J=3.0,12 \mathrm{H}, \mathrm{SiH} M e_{2}$ ). Anal. calcd. for $\mathrm{C}_{45} \mathrm{H}_{65} \mathrm{~N}_{2} \mathrm{O}_{3} \mathrm{ScSi}_{4}$ : C, 64.40; H, 7.81; N, 3.34. Found: C, $63.8 ; \mathrm{H}, 8.2 ; \mathrm{N}, 3.4$.

\section{$\left\{\mathrm{ONO}^{\text {SitBuMe2 }}\right\}$ Y $\left[\mathbf{N}\left(\mathrm{SiHMe}_{2}\right)_{2}\right]$ (THF) (5)}

This compound was prepared following the same procedure as that described above for $\mathbf{1}$, starting from $\left\{\mathrm{ONO}^{\mathrm{SitBuMe} 2}\right\} \mathrm{H}_{2}(0.063 \mathrm{~g}$, $0.110 \mathrm{mmol})$ and $\mathrm{Y}\left[\mathrm{N}\left(\mathrm{SiHMe}_{2}\right)_{2}\right]_{3}$ (THF) $(0.060 \mathrm{~g}, 0.110 \mathrm{mmol})$ in benzene $(5 \mathrm{~mL})$. Compound $\mathbf{5}$ was obtained as a pale yellow microcrystalline material $(0.083 \mathrm{~g}, 85 \%)$. Crystals of $\mathbf{5}$ suitable for $\mathrm{X}$-ray diffraction analysis were prepared by prolonged crystallization from a concentrated benzene solution at room temperature. ${ }^{1} \mathrm{H}$ NMR $\left(500 \mathrm{MHz}\right.$, benzene- $\left.d_{6}, 298 \mathrm{~K}\right): \delta 8.34\left(\mathrm{~s}, 2 \mathrm{H}, \mathrm{H}^{4}\right), 7.86$ $\left(\mathrm{d},{ }^{3} J=7.5,2 \mathrm{H}, \mathrm{H}^{5}\right), 7.79\left(\mathrm{br} \mathrm{d},{ }^{3} J=8.0,2 \mathrm{H}, \mathrm{H}^{8}\right), 7.36\left(\mathrm{t},{ }^{3} J=\right.$ 8.0, $2 \mathrm{H}, \mathrm{H}^{7}$ ), $7.28\left(\mathrm{~m}, 2 \mathrm{H}, \mathrm{H}^{6}\right), 7.19\left(\mathrm{br} \mathrm{d},{ }^{3} \mathrm{~J}=7.7,2 \mathrm{H}, \mathrm{H}^{2 \mathrm{p}}\right), 6.97$ (t, $\left.{ }^{3} J=7.7,1 \mathrm{H}, \mathrm{H}^{3 \mathrm{p}}\right), 4.76$ (br m, 2H, SiHMe), 4.01 (br m, 4H, $\alpha-$ $\mathrm{CH}_{2}, \mathrm{THF}$ ), 1.31 (br m, 4H, $\beta-\mathrm{CH}_{2}, \mathrm{THF}+18 \mathrm{H}, \mathrm{SiMe}_{2} t \mathrm{Bu}$ ), 0.78 (br s, 6H, SiMeMetBu), 0.71 (br s, 6H, SiMeMetBu), 0.03 (br s, $12 \mathrm{H}, \mathrm{SiHMe} 2) .{ }^{13} \mathrm{C}\left\{{ }^{1} \mathrm{H}\right\}$ NMR $\left(125 \mathrm{MHz}\right.$, benzene- $\left.d_{6}, 298 \mathrm{~K}\right): \delta$ 163.6, 140.4, 136.9, 136.0, 130.5, 128.8, 128.3, 128.1, 126.9, 126.7, 123.3, 121.7 (Caro), 70.9 ( $\left.\alpha-\mathrm{CH}_{2}, \mathrm{THF}\right), 27.7\left(\mathrm{C}\left(\mathrm{CH}_{3}\right)_{3}\right), 24.9$ ( $\beta$ $\left.\left.\mathrm{CH}_{2}, \mathrm{THF}\right), 17.9\left(\mathrm{C}_{(\mathrm{CH}}\right)_{3}\right), 3.0\left(\mathrm{SiMe} \mathrm{tBu}_{2}\right), 2.8\left(\mathrm{SiHMe}_{2}\right)$.. VT ${ }^{1} \mathrm{H}$ NMR: ${ }^{1} \mathrm{H}$ NMR $\left(500 \mathrm{MHz}\right.$, toluene- $\left.d_{8}, 338 \mathrm{~K}\right): \delta 8.16\left(\mathrm{~s}, 2 \mathrm{H}^{4}\right)$, $7.70\left(\mathrm{dd},{ }^{3} \mathrm{~J}=7.9\right.$ and $\left.1.5,2 \mathrm{H}^{5}\right), 7.65\left(\mathrm{br} \mathrm{dd},{ }^{3} \mathrm{~J}=8.3\right.$ and 1.1 , $\left.2 \mathrm{H}^{8}\right), 7.22\left(\mathrm{ddd},{ }^{3,3,4} \mathrm{~J}=8.3,6.8\right.$ and $\left.1.5,2 \mathrm{H}^{7}\right), 7.19\left(\mathrm{dd},{ }^{3} J=7.9\right.$ and $\left.0.6,2 \mathrm{H}^{2 \mathrm{p}}\right), 7.12\left(\mathrm{ddd},{ }^{3,3,4} J=7.9,6.8\right.$ and $\left.1.1,2 \mathrm{H}^{6}\right), 7.11(\mathrm{t}$, ${ }^{3} J=7.9,1 \mathrm{H}^{3 \mathrm{p}}$ ), 4.57 (br m, 2H, Si $H \mathrm{Me}$ ), 3.96 (br m, 4H, $\alpha-\mathrm{CH}_{2}$, THF), 1.44 (br m, 4H, $\left.\beta-\mathrm{CH}_{2}, \mathrm{THF}\right), 1.16$ (s, $18 \mathrm{H}, \mathrm{SiMe}_{2} t B u$ ), 0.60 (s, 12H, SiMe $t \mathrm{Bu}$ ), -0.15 (br d, $J=2.1,12 \mathrm{H}, \mathrm{SiH} M e_{2}$ ). ${ }^{1} \mathrm{H}$ NMR $\left(500 \mathrm{MHz}\right.$, toluene- $\left.d_{8}, 313 \mathrm{~K}\right): \delta 8.18\left(\mathrm{~s}, 2 \mathrm{H}^{4}\right), 7.71(\mathrm{dd}$, $\left.{ }^{3} J=7.9,1.3,2 \mathrm{H}^{5}\right), 7.63\left(\right.$ br dd, ${ }^{3} J=8.1$ and $\left.1.1,2 \mathrm{H}^{8}\right), 7.23(\mathrm{ddd}$, ${ }^{3,3,4} \mathrm{~J}=8.1,6.6$, and $\left.1.3,2 \mathrm{H}^{7}\right), 7.14\left(\mathrm{ddd},{ }^{3,3,4} \mathrm{~J}=7.9,6.6\right.$, and 1.1 , $\left.2 \mathrm{H}^{6}\right), 7.13\left(\mathrm{~m}, 2 \mathrm{H}^{2 \mathrm{p}}\right), 7.05$ (br m, $\left.1 \mathrm{H}^{3 \mathrm{p}}\right), 4.64$ (br m, 2H, Si $H \mathrm{Me}$ ), 3.92 (br m, 4H, $\alpha-\mathrm{CH}_{2}$, THF), 1.32 (br m, 4H, $\beta$-CH $\mathrm{H}_{2}, \mathrm{THF}$ ), 1.19 (s, $18 \mathrm{H}, \mathrm{SiMe}_{2} t \mathrm{Bu}$ ), 0.67 (br s, 6H, SiMeMetBu), 0.61 (br s, $6 \mathrm{H}$, $\mathrm{SiMeMe} t \mathrm{Bu}$ ), -0.05 (br s, $\left.12 \mathrm{H}, \mathrm{SiH} M e_{2}\right) .{ }^{1} \mathrm{H}$ NMR $(500 \mathrm{MHz}$, toluene- $\left.d_{8}, 296 \mathrm{~K}\right): \delta 8.19\left(\mathrm{~s}, 2 \mathrm{H}^{4}\right), 7.72\left(\mathrm{dd},{ }^{3} J=7.7\right.$ and 1.5 , $\left.2 \mathrm{H}^{5}\right), 7.64\left(\right.$ br s, $\left.2 \mathrm{H}^{8}\right), 7.24\left(\mathrm{ddd},{ }^{3,3,4} J=8.3,6.8\right.$, and $\left.1.5,2 \mathrm{H}^{7}\right)$, $7.15\left(\mathrm{ddd},{ }^{3,3,4} J=1.1,6.8\right.$, and $\left.7.7,2 \mathrm{H}^{6}\right), 7.11\left(\mathrm{br} \mathrm{m}, 2 \mathrm{H}^{2 \mathrm{p}}\right), 7.06(\mathrm{br}$ m, $1 \mathrm{H}^{3 \mathrm{p}}$ ), 4.66 (br m, 2H, Si HMe), 3.91 (br m, 4H, $\alpha-\mathrm{CH}_{2}, \mathrm{THF}$ ), 1.31 (br m, 4H, $\beta-\mathrm{CH}_{2}$, THF), 1.20 (s, 18H, $\mathrm{SiMe}_{2} t \mathrm{Bu}$ ), 0.70 (br s, $6 \mathrm{H}, \mathrm{SiMeMe} t \mathrm{Bu}$ ), 0.62 (br s, 6H, SiMeMet $\mathrm{Bu}$ ),-0.01 (br s, $12 \mathrm{H}$, $\left.\mathrm{SiH} M e_{2}\right) .{ }^{1} \mathrm{H}$ NMR $\left(500 \mathrm{MHz}\right.$, toluene- $\left.d_{8}, 263 \mathrm{~K}\right): \delta 8.23\left(\mathrm{~s}, 2 \mathrm{H}^{4}\right)$, $7.73\left(\right.$ br d, $\left.{ }^{3} J=7.9,2 \mathrm{H}^{5}\right), 7.73\left(\right.$ br m, $2 \mathrm{H}^{8}$ ), 7.26 (br m, $\left.2 \mathrm{H}^{7}\right), 7.16$ (br m, $4 \mathrm{H}^{6+2 \mathrm{p}}$ ), 6.88 (br tr, ${ }^{3} J=7.9,1 \mathrm{H}^{3 \mathrm{p}}$ ), 4.51 (br m, $2 \mathrm{H}, \mathrm{Si} H \mathrm{Me}$ ), 3.69 (br m, $4 \mathrm{H}, \alpha-\mathrm{CH}_{2}$, THF), 1.33 (br m, 4H, $\beta-\mathrm{CH}_{2}, \mathrm{THF}$ ), 1.24 (s, $18 \mathrm{H}, \mathrm{SiMe}_{2} t \mathrm{Bu}$ ), 0.63 (br s, 12H, SiMe $\left.t \mathrm{Bu}\right),-0.27$ (br s, 12H, $\left.\mathrm{SiHMe} e_{2}\right) .{ }^{1} \mathrm{H}$ NMR $\left(500 \mathrm{MHz}\right.$, toluene- $\left.d_{8}, 233 \mathrm{~K}\right): \delta 8.27\left(\mathrm{~s}, 2 \mathrm{H}^{4}\right)$, 7.77 (m, 3H), $7.53(\mathrm{~m}, 1 \mathrm{H}), 7.27$ (m, 3H), 7.11 (br s, 2H), 6.78 (m, 2H), 4.53 (br m, 2H, SiHMe), 4.15 (br m, 2H, $\alpha-\mathrm{CH}_{2}, \mathrm{THF}$ ), 3.66 (br m, 2H, $\alpha-\mathrm{CH}_{2}, \mathrm{THF}$ ), 1.35 (br m, $4 \mathrm{H}, \beta-\mathrm{CH}_{2}, \mathrm{THF}$ ), 1.25 (s, 18H, $\mathrm{SiMe}_{2} t B u$ ), 0.64 (br s, 6H, SiMeMet Bu), 0.62 (br s, $6 \mathrm{H}, \mathrm{SiMeMe} t \mathrm{Bu}$ ), -0.24 (br s, $12 \mathrm{H}, \mathrm{SiH} M e_{2}$ ). Anal. calcd. for $\mathrm{C}_{45} \mathrm{H}_{65} \mathrm{~N}_{2} \mathrm{O}_{3} \mathrm{Si}_{4} \mathrm{Y}$ : C, 61.19; H, 7.42; N, 3.17. Found: C, 60.8; H, $8.1 ; \mathrm{N}, 3.0$.

\section{NMR-scale generation of $\left\{\mathrm{ONO}^{\mathrm{SitBuMe} 2}\right\} \mathrm{La}\left[\mathrm{N}\left(\mathrm{SiHMe}_{2}\right)_{2}\right](\mathrm{THF})$ (6)}

Complex 6 was generated in situ from the 1:1 reaction of $\left\{\mathrm{ONO}^{\mathrm{SitBuMe} 2}\right\} \mathrm{H}_{2}$ with $\mathrm{La}\left[\mathrm{N}\left(\mathrm{SiHMe}_{2}\right)_{2}\right]_{3}(\mathrm{THF})_{2}$. The ${ }^{1} \mathrm{H} \mathrm{NMR}$ spectrum of the reaction mixture was quite complicated and could not be unambiguously assigned. 


\section{$\left\{\mathrm{OSO}^{\mathrm{SiPh3}}\right\} \mathrm{Sc}\left[\mathbf{N}\left(\mathrm{SiHMe}_{2}\right)_{2}\right](\mathrm{THF})(7)$}

This compound was prepared following the same procedure as that described above for $\mathbf{1}$, starting from $\left\{\mathrm{OSO}^{\mathrm{SiPh} 3}\right\} \mathrm{H}_{2}(0.068 \mathrm{~g}$, $0.090 \mathrm{mmol})$ and $\mathrm{Sc}\left[\mathrm{N}(\mathrm{SiHMe})_{2}\right]_{3}(\mathrm{THF})(0.040 \mathrm{~g}, 0.090 \mathrm{mmol})$ in benzene $(5 \mathrm{~mL})$. Compound 7 was obtained as a pale yellow microcrystalline powder $(0.076 \mathrm{~g}, 75 \%)$. Crystals of 7 suitable for $\mathrm{X}$-ray diffraction analysis were prepared by prolonged crystallization from a concentrated benzene solution at room temperature. ${ }^{1} \mathrm{H}$ NMR (500 MHz, benzene- $\left.d_{6}, 298 \mathrm{~K}\right): \delta 8.35\left(\mathrm{~d},{ }^{3} \mathrm{~J}=8.4,2 \mathrm{H}\right.$, Haro) $8.06\left(\mathrm{~s}, 2 \mathrm{H}, \mathrm{H}^{4}\right), 7.81-7.83\left(\mathrm{~m}, 12 \mathrm{H}\right.$, Haro), $7.53\left(\mathrm{t},{ }^{3} \mathrm{~J}=\right.$ 7.6, $\left.2 \mathrm{H}, \mathrm{H}^{7}\right), 7.49$ (s, $2 \mathrm{H}$, thiophene), $7.43\left(\mathrm{~d},{ }^{3} J=7.6,2 \mathrm{H}, \mathrm{H}^{8}\right)$, 7.26-7.30 (m, 18H, Haro), $7.15\left(\mathrm{t},{ }^{3} J=7.7,2 \mathrm{H}, \mathrm{H}^{6}\right), 4.34$ (sept, ${ }^{3} J=2.9,2 \mathrm{H}, \mathrm{SiHMe}$ ), 2.82 (m, 4H, $\left.\alpha-\mathrm{CH}_{2}, \mathrm{THF}\right), 0.69$ (m, 4H, $\left.\beta-\mathrm{CH}_{2}, \mathrm{THF}\right), 0.05$ (d, $\left.{ }^{3} \mathrm{~J}=3.2,12 \mathrm{H}, \mathrm{SiH} M e_{2}\right) .{ }^{13} \mathrm{C}\left\{{ }^{1} \mathrm{H}\right\} \mathrm{NMR}$ (125 MHz, benzene- $d_{6}, 298 \mathrm{~K}$ ): $\delta 168.8,143.7,141.4,136.6,136.5$, $134.9,133.5,129.2,129.1,128.3,128.1,128.0,127.6,125.5,123.4$, 122.3, 115.4 (Caro), 71.6 ( $\left.\alpha-\mathrm{CH}_{2}, \mathrm{THF}\right), 24.4$ ( $\left.\beta-\mathrm{CH}_{2}, \mathrm{THF}\right), 2.8$ $\left(\mathrm{SiH} M e_{2}\right)$. Anal. calcd. for $\mathrm{C}_{68} \mathrm{H}_{64} \mathrm{NO}_{3} \mathrm{SScSi}_{4}: \mathrm{C}, 72.11 ; \mathrm{H}, 5.70$; N, 1.24. Found: C, 71.8; H, 6.1; N, 1.2.

\section{$\left\{\mathrm{OSO}^{\mathrm{SiPh3}}\right\} \mathrm{Y}\left[\mathrm{N}\left(\mathrm{SiHMe}_{2}\right)_{2}\right](\mathrm{THF})(8)$}

This compound was prepared following the same procedure as that described above for $\mathbf{1}$, starting from $\left\{\mathrm{OSO}^{\mathrm{Siph} 3}\right\} \mathrm{H}_{2}(0.064 \mathrm{~g}$, $0.070 \mathrm{mmol})$ and $\mathrm{Y}\left[\mathrm{N}\left(\mathrm{SiHMe}_{2}\right)_{2}\right]_{3}$ (THF) $(0.040 \mathrm{~g}, 0.070 \mathrm{mmol})$ in benzene $(5 \mathrm{~mL})$. Compound $\mathbf{8}$ was obtained as a pale yellow microcrystalline powder $(0.065 \mathrm{~g}, 81 \%) .{ }^{1} \mathrm{H}$ NMR $(500 \mathrm{MHz}$, benzene- $\left.d_{6}, 298 \mathrm{~K}\right): \delta 8.08\left(\mathrm{~s}, 2 \mathrm{H}, \mathrm{H}^{4}\right), 7.94\left(\mathrm{~d},{ }^{3} J=8.4,2 \mathrm{H}\right.$, Haro), 7.85-7.87 (m, 12H, Haro), 7.55 (s, 2H, thiophene), 7.49 (t, $\left.{ }^{3} J=7.8,2 \mathrm{H}\right), 7.42\left(\mathrm{~d},{ }^{3} J=7.8,2 \mathrm{H}\right.$, Haro $), 7.27-7.31(\mathrm{~m}, 18 \mathrm{H}$, Haro), $7.13\left(\mathrm{t},{ }^{3} J=7.8,2 \mathrm{H}\right), 4.55\left(\mathrm{sept},{ }^{3} J=2.9,2 \mathrm{H}, \mathrm{Si} H \mathrm{Me}\right)$, 2.85 (m, 4H, $\left.\alpha-\mathrm{CH}_{2}, \mathrm{THF}\right), 0.68$ (m, 4H, $\left.\beta-\mathrm{CH}_{2}, \mathrm{THF}\right), 0.14$ (d, $\left.{ }^{3} J=2.9,12 \mathrm{H}, \mathrm{SiH} M e\right) \cdot{ }^{13} \mathrm{C}\left\{{ }^{1} \mathrm{H}\right\}$ NMR $\left(125 \mathrm{MHz}\right.$, benzene- $d_{6}, 298$ $\mathrm{K}): \delta 171.8,149.6,144.2,136.8,136.7,136.4,135.6,132.4,129.2$, 128.4, 128.1, 127.6, 126.9, 126.6, 122.6, 121.8, 112.1 (Caro), 70.6 ( $\left.\alpha-\mathrm{CH}_{2}, \mathrm{THF}\right), 24.4\left(\beta-\mathrm{CH}_{2}, \mathrm{THF}\right), 3.4\left(\mathrm{SiHMe}_{2}\right)$. Anal. calcd. for $\mathrm{C}_{68} \mathrm{H}_{64} \mathrm{NO}_{3} \mathrm{SSi}_{4} \mathrm{Y}$ : C, 69.42; H, 5.48; N, 1.19. Found: C, 68.8; $\mathrm{H}, 5.37 ; \mathrm{N}, 1.2$

\section{$\left\{\right.$ OSO $\left.^{\mathrm{SiPh3}}\right\} \mathrm{La}\left[\mathbf{N}\left(\mathrm{SiHMe}_{2}\right)_{2}\right](\mathrm{THF})(9)$}

This compound was prepared following the same procedure as that described above for 1 , starting from $\left\{\mathrm{OSO}^{\mathrm{SiPh} 3}\right\} \mathrm{H}_{2}(0.165 \mathrm{~g}$, $0.180 \mathrm{mmol})$ and $\mathrm{La}\left[\mathrm{N}\left(\mathrm{SiHMe}_{2}\right)_{2}\right]_{3}(\mathrm{THF})_{2}(0.127 \mathrm{~g}, 0.180 \mathrm{mmol})$ in benzene $(10 \mathrm{~mL})$. Compound 9 was obtained as a pale yellow microcrystalline powder $(0.224 \mathrm{~g}, 96 \%)$. Crystals of 9 suitable for X-ray diffraction analysis were prepared by prolonged crystallization from a benzene solution at room temperature. ${ }^{1} \mathrm{H}$ NMR $\left(500 \mathrm{MHz}\right.$, benzene- $\left.d_{6}, 298 \mathrm{~K}\right): \delta 8.08\left(\mathrm{~s}, 2 \mathrm{H}, \mathrm{H}^{4}\right), 7.94$ $\left(\mathrm{d},{ }^{3} \mathrm{~J}=8.3 \mathrm{~Hz}, 2 \mathrm{H}\right.$, Haro), 7.89 (m, 12H, Haro), 7.52 (s, 2H, thiophene), 7.49 ( $\mathrm{m}, 2 \mathrm{H}, \mathrm{Haro}), 7.42\left(\mathrm{~d},{ }^{3} J=8.3,2 \mathrm{H}\right.$, Haro), 7.33 (m, 18H, Haro), 7.13 (m, 2H, Haro), 4.55 (sept, ${ }^{3} J=2.8,2 \mathrm{H}$, $\mathrm{Si} H \mathrm{Me}$ ), 2.70 (br m, 4H, $\alpha-\mathrm{CH}_{2}, \mathrm{THF}$ ), 0.76 (br m, 4H, $\beta-\mathrm{CH}_{2}$, THF), 0.19 (d, $\left.{ }^{3} J=2.8,12 \mathrm{H}, \mathrm{SiH} M e_{2}\right) .{ }^{13} \mathrm{C}\left\{{ }^{1} \mathrm{H}\right\} \mathrm{NMR}(125 \mathrm{MHz}$, benzene- $\left.d_{6}, 298 \mathrm{~K}\right): \delta 173.0,151.8,143.8,136.6,136.5,136.1$, 132.0, 129.1, 129.0, 128.1, 127.9, 126.9, 126.6, 122.7, 121.5, 111.6 (Caro), 69.1 ( $\alpha-\mathrm{CH}_{2}$, THF), 24.5 ( $\beta-\mathrm{CH}_{2}$, THF), $3.1\left(\mathrm{SiHMe}_{2}\right)$. Anal. calcd. for $\mathrm{C}_{68} \mathrm{H}_{64} \mathrm{LaNO}_{3} \mathrm{SSi}_{4}$ : C, 66.59; H, 5.26; N, 1.14 . Found: C, 66.8; H, 5.57; N, 1.0.

\section{Crystal structure determination of complexes 3-5, 7, 9 and 10}

Suitable crystals for X-ray diffraction analysis of 3-5, 7, 9 and 10 were obtained by crystallization of purified products from concentrated benzene solutions (see the Experimental section and body text). Diffraction data were collected at $100 \mathrm{~K}$ using a Bruker APEX CCD diffractometer with graphite-monochromated Mo$\mathrm{K} \alpha$ radiation $(\lambda=0.71073 \AA)$. A combination of $\omega$ and $\phi$ scans was carried out to obtain at least a unique data set. The crystal structures were solved by direct methods using the SIR97 program ${ }^{30}$ remaining atoms were located from difference Fourier synthesis followed by full-matrix least-squares refinement based on $F^{2}$ (programs SHELXS-97 and SHELXL-97) ${ }^{31}$ with the aid of the WINGX program. ${ }^{32}$ Many hydrogen atoms could be found from the Fourier difference analysis. Carbon- and oxygen-bound hydrogen atoms were placed at calculated positions and forced to ride on the attached atom. The hydrogen atom contributions were calculated but not refined. All non-hydrogen atoms were refined with anisotropic displacement parameters. The locations of the largest peaks in the final difference Fourier map calculation as well as the magnitude of the residual electron densities were of no chemical significance. In $\mathbf{4}$ and $\mathbf{5}$, one $t \mathrm{Bu}$ group and one $\mathrm{Si}(2)-$ Me group were found to be disordered and accordingly modelled. Crystals of $\mathbf{1 0}$ were found to contain lattice disordered solvent molecules (benzene), all of which could not be satisfactorily modelled and were removed using the SQUEEZE procedure ${ }^{33}$ implemented in the PLATON package. ${ }^{34}$ Crystal data and details of data collection and structure refinement for the different compounds are given in Table 1. Crystallographic data are also available as cif files (see the ESI $\dagger$ ).

\section{Typical procedure for $r a c-\mathrm{LA}$ and $r a c-B B L$ polymerization}

In a glovebox, a Schlenk flask was charged with a solution of complex $1(7.0 \mathrm{mg}, 5.8 \mu \mathrm{mol})$ in THF or toluene $(0.20-0.60 \mathrm{~mL})$. To this solution, the monomer $(0.58 \mathrm{mmol}, 100$ equiv $v s$. La; racLA: $82.6 \mathrm{mg}$, rac-BBL: $49.3 \mathrm{mg}$ ) was rapidly added under vigorous stirring at $20{ }^{\circ} \mathrm{C}$. Small aliquots of the reaction mixture were periodically sampled with pipette for determining the conversion by ${ }^{1} \mathrm{H}$ NMR spectrometry. After the desired time, the reaction was quenched by adding acidic methanol ( $c a .1 \mathrm{~mL}$ of a $1.2 \mathrm{M} \mathrm{HCl}$ solution in $\mathrm{CH}_{3} \mathrm{OH}$ ) and the polymer was precipitated with excess methanol ( $c a .3 \mathrm{~mL})$. The supernatant solution was removed with pipette and the polymer was dried under vacuum to constant weight.

\section{Acknowledgements}

This work was financially supported by Agence Nationale de la Recherche (grant ANR-06-BLAN-0213). JFC gratefully thanks the Institut Universitaire de France for a Junior IUF fellowship (2005-2009).

\section{References}

1 For reviews on alkoxo- and aryloxo-metal chemistry, see: (a) D. C. Bradley, R. M. Mehrotra, I. P. Rothwell, A. Singh Alkoxo and Aryloxo Derivatives of Metals, Academic Press, London, 2001; (b) R. M Mehrotra and A. Singh, Prog. Inorg. Chem., 1997, 46, 239; (c) R. C. Mehrotra, A. Singh and U. M. Triptathi, Chem. Rev., 1991, 91, 1287. 
2 For selected leading references, see: (a) J. Tian and G. W. Coates, Angew. Chem., Int. Ed., 2000, 39, 3626; (b) P. D. Hustad, J. Tian and G. W. Coates, J. Am. Chem. Soc., 2002, 124, 3614; (c) S. Reinartz, A. F. Mason, E. B. Lobkovsky and G. W. Coates, Organometallics, 2003, 22, 2542; (d) A. F. Mason and G. W. Coates, J. Am. Chem. Soc., 2004, 126, 10798; (e) A. F. Mason and G. W. Coates, J. Am. Chem. Soc., 2004, 126, 16326; $(f)$ J. Saito, M. Mitani, J. Mohri, Y. Yoshida, S. Matsui, S. Ishii, S. Kojoh, N. Kashiwa and T. Fujita, Angew. Chem., Int. Ed., 2001, 40, 2918; (g) S. Matsui, M. Mitani, J. Saito, Y. Tohi, H. Makio, N. Matsukawa, Y. Takagi, K. Tsuru, M. Nitabaru, T. Nakano, H. Tanaka, N. Kashiwa and T. Fujita, J. Am. Chem. Soc., 2001, 123, 6847; (h) T. Matsugi and F. Fujita, Chem. Soc. Rev., 2008, 37, 1264.

3 For selected leading references, see: $(a)$ R. M. Gauvin, J. A. Osborn and J. Kress, Organometallics, 2000, 19, 2944; (b) K. Takaoki and T. Miyatake, Macromol. Symp., 2000, 157, 251; (c) Y. Nakayama, K. Watanabe, N. Ueyama, A. Nakamura, A. Harada and J. Okuda, Organometallics, 2000, 19, 2498; (d) M. C. W. Chan, K. H. Tam, Y. L. Pui and N. Y. Zhu, J. Chem. Soc., Dalton Trans., 2002, 3085; (e) M. C. W. Chan, K. H. Tam, N. Y. Zhu, P. Chiu and S. Matsui, Organometallics, 2006, 25, 785; $(f)$ T. Agapie, L. M. Henling, A. G. DiPasquale, A. L. Rheingold and J. E. Bercaw, Organometallics, 2008, 27, 6245.

4 For selected leading references, see: (a) E. Y. Tshuva, I. Goldberg, M. Kol, H. Weitman and Z. Goldschmidt, Chem. Commun., 2000, 379; (b) E. Y. Tshuva, I. Goldberg and M. Kol, J. Am. Chem. Soc., 2000, 122, 10706; (c) E. Y. Tshuva, I. Goldberg, M. Kol and Z. Goldschmidt, Chem. Commun., 2001, 2120; (d) E. Y. Tshuva, I. Goldberg and M. Kol, J. Am. Chem. Soc., 2001, 123, 3621; (e) E. Y. Tshuva, I. Goldberg, M. Kol and Z. Goldschmidt, Organometallics, 2001, 20, 3017; $(f)$ E. Y. Tshuva, S. Groysman, I. Goldberg, M. Kol and Z. Goldschmidt, Organometallics, 2002, 21, 662; (g) S. Groysman, E. Y. Tshuva, I. Goldberg, M. Kol, Z. Goldschmidt and M. Shuster, Organometallics, 2004, 23, 5291; (h) S. Segal, I. Goldberg and M. Kol, Organometallics, 2005, 24, 200; (i) C. Capacchione, A. Proto, H. Ebeling, R. Mulhaupt, K. Moller, T. P. Spaniol and J. Okuda, J. Am. Chem. Soc., 2003, 125, 4964; (j) C. Capacchione, F. De Carlo, C. Zannoni, J. Okuda and A. Proto, Macromolecules, 2004, 37, 8918; (k) B. Lian, T. P. Spaniol and J. Okuda, Organometallics, 2007, 26, 6653; (l) G. J. M. Meppelder, K. Beckerle, R. Manivannan and J. Okuda, Chem.-Asian J., 2008, 3, 1312.

5 For leading reviews on "post-metallocene" complexes of groups 3-6 and the lanthanides related to olefin oligo/polymerization, see: (a) G. J. P. Britovsek, V. C. Gibson and D. F. Wass, Angew. Chem., Int. Ed., 1999, 38, 428; (b) G. W. Coates, P. D. Hustad and S. Reinartz, Angew. Chem., Int. Ed., 2002, 41, 2236; (c) F. T. Edelmann, D. M. M. Freckmann and H. Schumann, Chem. Rev., 2002, 102, 1851; (d) V. C. Gibson and S. K. Spitzmesser, Chem. Rev., 2003, 103, 283; (e) J. Gromada, A. Mortreux and J.-F. Carpentier, Coord. Chem. Rev., 2004, 248, 397; (f) P. Corradini, G. Guerra and L. Cavallo, Acc. Chem. Res., 2004, 37, 231; (g) M. Kol, S. Segal, S. Groysman in Stereoselective Polymerization with Single-Site Catalysts, CRC Press LLC, Boca Raton, Fla, 2008, pp. 345-361; (h) J. Okuda, Stud. Surf. Sci. Catal., 2007, 172, 11; (i) G. J. Domski, J. M. Rose, G. W. Coates, A. D. Bolig and M. Brookhart, Prog. Polym. Sci., 2007, 32, 30 .

6 For leading reviews, see: O. Dechy-Cabaret, B. Martin-Vaca and D. Bourissou, Chem. Rev., 2004, 104, 6147(a) B. J. O'Keefe, M. A. Hillmyer and W. B. Tolman, J. Chem. Soc., Dalton Trans., 2001, 2215; (b) J. Wu, T.-L. Yu, C.-T. Chen and C.-C. Lin, Coord. Chem. Rev., 2006, 250, 602; (c) A. Amgoune, C. M. Thomas and J.-F. Carpentier, Pure Appl. Chem., 2007, 79, 2013; $(d)$ R. H. Platel, L. M. Hodgson and C. K. Williams, Polym. Rev., 2008, 48, 11; (e) A. P. Dove, Chem. Commun., 2008, 6446.

7 (a) C.-X. Cai, L. Toupet and J.-F. Carpentier, J. Organomet. Chem., 2003, 683, 131; (b) C.-X. Cai, A. Amgoune, C. W. Lehmann and J.F. Carpentier, Chem. Commun., 2004, 330; (c) A. Amgoune, C. M. Thomas, T. Roisnel and J.-F. Carpentier, Chem.-Eur. J., 2006, 12 169; (d) A. Amgoune, C. M. Thomas, S. Ilinca, T. Roisnel and J.-F. Carpentier, Angew. Chem., Int. Ed., 2006, 45, 2782; (e) A. Amgoune, C.M. Thomas and J.-F. Carpentier, Macromol. Rapid Commun., 2007, 28, 693; $(f)$ N. Ajellal, M. Bouyahyi, A. Amgoune, C. M. Thomas, A. Bondon, I. Pillin, Y. Grohens and J.-F. Carpentier, Macromolecules, 2009, 42, 987; ( $g$ ) H. Ma, T. P. Spaniol and J. Okuda, Dalton Trans., 2003, 4770; (h) H. Y. Ma and J. Okuda, Macromolecules, 2005, 38, 2665; (i) H. Y. Ma, T. P. Spaniol and J. Okuda, Angew. Chem., Int. Ed., 2006, 45, 7818; (j) H. Ma, T. P. Spaniol and J. Okuda, Inorg. Chem., 2008, 47, 3328; (k) F. Bonnet, A. R. Cowley and P. Mountford, Inorg. Chem.,
2005, 44, 9046; (l) X. Liu, X. Shang, T. Tang, N. Hu, F. Pei, D. Cui, X. Chen and X. Jing, Organometallics, 2007, 26, 2747; $(m)$ P. I. Binda and E. E. Delbridge, Dalton Trans., 2007, 4685.

8 (a) Y. Takashima, Y. Nakayama, K. Watanabe, T. Itono, N. Ueyama, A. Nakamura, H. Yasuda, A. Harada and J. Okuda, Macromolecules, 2002, 35, 7538; (b) Y. Sarazin, R. Howard, D. Hughes, S. Humphrey and M. Bochmann, Dalton Trans., 2006, 340; (c) S. Gendler, S. Segal, I. Goldberg, Z. Goldschmidt and M. Kol, Inorg. Chem., 2006, 45, 4783; (d) A. J. Chmura, M. G. Davidson, M. D. Jones, M. D. Lunn, M. F. Mahon, A. F. Johnson, P. Khunkamchoo, S. L. Roberts and S. S. F. Wong, Macromolecules, 2006, 39, 7250; (e) A. J. Chmura, M. G. Davidson, C. J. Frankis, M. D. Jones and M. D. Lunn, Chem. Commun., 2008, 1293.

9 S. Steinhauser, U. Heinz, J. Sander and K. Hegetschweiler, Z. Anorg. Allg. Chem., 2004, 630, 1829.

10 Y. Q. Li, Y. Liu, W. M. Bu, J. H. Guo and Y. Wang, Chem. Commun., $2000,1551$.

11 (a) E. Kirillov, J.-F. Carpentier and A. Razavi, Eur. Pat. Appl., 2008, 290, p. 410.3; (b) E. Kirillov, T. Roisnel, A. Razavi and J.-F. Carpentier, Organometallics, 2009, 28, 5036.

12 The following atom numbering of the naphtholate unit is used:

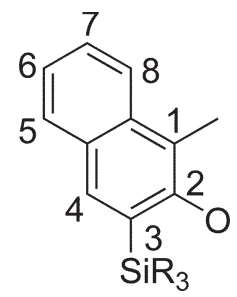

13 For additional examples of ROP of lactide and $\beta$-butyrolactone with group 3 metal and lanthanide complexes, see: $(a) \mathrm{A}$. Le Borgne, C. Pluta and N. Spassky, Macromol. Rapid Commun., 1994, 15, 955; (b) N. Spassky, V. Simic, M. S. Montaudo and L. G. Hubert-Pfalzgraf, Macromol. Chem. Phys., 2000, 201, 2432; (c) K. B. Aubrecht, K. Chang, M. A. Hillmyer and W. B. Tolman, J. Polym. Sci., Part A: Polym. Chem., 2001, 39, 284; (d) G. R. Giesbrecht, G. D. Whitener and J. Arnold, J. Chem. Soc., Dalton Trans., 2001, 923; (e) T. M. Ovitt and G.W. Coates, J. Am. Chem. Soc., 2002, 124, 1316; (f) Y. Satoh, N. Ikitake, Y. Nakayama, S. Okuno and H. Yasuda, J. Organomet. Chem., 2003, 667, 42; $(g)$ L. Zhang, Z. Shen, C. Yu and L. Fan, J. Macromol. Sci. Part A: Pure Appl. Chem., 2004, 41, 927; (h) I. Westmoreland and J. Arnold, Dalton Trans., 2006, 4155; (i) A. Alaaeddine, A. Amgoune, C. M. Thomas, S. Dagorne, S. Bellemin-Laponnaz and J.-F. Carpentier, Eur. J. Inorg. Chem., 2006, 3652; (j) J. Wang, T. Cai, Y. Yao and Q. Shen, Dalton Trans., 2007, 5275; (k) S. Wang, S. Wang, S. Zhou, G. Yang, W. Luo, N. Hu, Z. Zhou and H.-B. Song, J. Organomet. Chem., 2007, 692, 2099; (l) S. Zhou, S. Wang, E. Sheng, L. Zhang, Z. Yu, X. Xi, G. Chen, W. Luo and Y. Li, Eur. J. Inorg. Chem., 2007, 1519; $(m)$ H. Zhou, H. Guo, Y. Yao, L. Zhou, H. Sun, H. Sheng, Y. Zhang and Q. Shen, Inorg. Chem., 2007, 46, 958; (n) M. T. Gamer, P. W. Roesky, I. Pallard, M. Le Hellaye and S. M. Guillaume, Organometallics, 2007, 26, 651; (o) E. E. Delbridge, D. T. Dugah, C. R. Nelson, B. W. Skelton and A. H. White, Dalton Trans., 2007, 143; ( $p$ ) G. G. Skvortsov, M. V. Yakovenko, P. M. Castro, G. K. Fukin, A. V. Cherkasov, J.-F. Carpentier and A. A. Trifonov, Eur. J. Inorg. Chem., 2007, 3260; (q) R. Heck, E. Schulz, J. Collin and J.-F. Carpentier, J. Mol. Catal. A: Chem., 2007, 268, 163; $(r)$ N. Ajellal, D. M. Lyubov, M. A. Sinenkov, G. K. Fukin, A. V. Cherkasov, C. M. Thomas, J.-F. Carpentier and A. A. Trifonov, Chem.-Eur. J., 2008, 14, 5440; $(s)$ T. V. Mahrova, G. K. Fukin, A. V. Cherkasov, A. A. Trifonov, N. Ajellal and J.-F. Carpentier, Inorg. Chem., 2009, 48, 4258 .

14 (a) R. Anwander, O. Runte, J. Eppinger, G. Gerstberger, E. Herdtweck and M. Spiegler, J. Chem. Soc., Dalton Trans., 1998, 847; (b) J. Eppinger, M. Speigler, W. Hieringer, W. A. Herrmann and R. Anwander, J. Am. Chem. Soc., 2000, 122, 3080.

15 Note that the $C 2$ and $C$ s symmetry refers here to the coordination mode of the ligand, but not to the complex because of the position of the amide and THF ligands.

16 As revealed by significant broadening of the $\alpha$-THF hydrogens at intermediate temperatures ( $c a$. room temperature), the same dynamic phenomena take place in scandium compound $\mathbf{4}$, but the resonances for the diastereotopic $\alpha$-THF hydrogens appear incidentally isochronic in this case. 
17 A. Alaaeddine, C. M. Thomas, T. Roisnel and J.-F. Carpentier, Organometallics, 2009, 28, 1469.

18 Ionic radii (in $\AA$ ) for six-coordinated metal centers: $\mathrm{Sc}^{3+}, 0.75 ; \mathrm{Y}^{3+}, 0.90$; $\mathrm{La}^{3+}, 1.17 ; \mathrm{Ti}^{4+}, 0.61: \mathrm{Zr}^{4+}, 0.72 ; \mathrm{Hf}^{4+}, 0.71 ; \mathrm{Ta}^{5+}, 0.64$. R. D. Shannon, Acta Crystallogr., Sect. A: Cryst. Phys., Diffr., Theor. Gen. Crystallogr., 1976, A32, 751.

19 T. Agapie, M. W. Day and J. E. Bercaw, Organometallics, 2008, 27, 6123.

20 (a) P. N. O'Shaughnessy, P. D. Knight, C. Morton, K. M. Gillespie and P. Scott, Chem. Commun., 2003, 1770; (b) D. V. Gribkov, K. C. Hultzsch and F. Hampel, Chem.-Eur. J., 2003, 9, 4796.

21 (a) L. Lavanant, T.-Y. Chou, Y. Chi, C. W. Lehmann, L. Toupet and J.-F. Carpentier, Organometallics, 2004, 23, 5450; (b) E. Grunova, E. Kirillov, T. Roisnel and J.-F. Carpentier, Organometallics, 2008, 27, 5691.

22 (a) C. Runschke and G. Meyer, Z. Anorg. Allg. Chem., 1997, 623, 1493; (b) Y. Li, F.-K. Zheng, X. Liu, W.-Q. Zou, G.-C. Guo, C.-Z. Lu and J.-S. Huang, Inorg. Chem., 2006, 45, 6308; (c) L. Natrajan, J. Pecaut and M. Mazzanti, Dalton Trans., 2006, 1002.

23 In some cases, for convenience, in situ combinations of the pro-ligand $\left\{\mathrm{OZO}^{\mathrm{SiR} 3}\right\} \mathrm{H} 2$ with the tris(amido) precursor were investigated instead of isolated compounds. We independently checked for $\mathbf{2}$ and $\mathbf{3}$ that the corresponding in situ systems lead to similar polymerization results.

24 I. Barakat, P. Dubois, R. Jerome and P. Teyssie, J. Polym. Sci., Part A: Polym. Chem., 1993, 31, 505-514.

25 For low molar mass PLAs generated in the presence of isopropanol, determination of the number-average molar mass by ${ }^{1} \mathrm{H}$ NMR [from the relative intensity of the signals of the methyl hydrogens of the PLA chains to the methyl hydrogens of the $\mathrm{C}(\mathrm{O}) \mathrm{OCH}\left(\mathrm{CH}_{3}\right)_{2}$ end-groups] gave values in close agreement with those determined by SEC analysis.

26 MALDI-ToF-MS analysis of some PLA samples recovered at high monomer conversions $(>95 \%)$ showed distributions containing both even-membered and odd-membered oligomers, with peaks separated by $72 \mathrm{Da}$. This unambiguously established that transesterification processes take place in these systems, especially in the later stages of the polymerization.

27 (a) For the pioneering work of Inoue in the immortal polymerizations of epoxides initiated with zinc complexes of $N$-substituted porphyrins, see: Y. Watanabe, T. Aida and S. Inoue, Macromolecules, 1990, 23, 2612. For application of this concept to the highly efficient immortal ROP of lactide and cyclic carbonates, see: (b) M. Helou, O. Miserque, J.-M. Brusson, J.-F. Carpentier and S. M. Guillaume, Chem.-Eur. J., 2008, 14, 8772; (c) V. Poirier, T. Roisnel, J.-F. Carpentier and Y. Sarazin, Dalton Trans., 2009, 9820.

28 Detailed microstructural analysis of the PLAs by ${ }^{13} \mathrm{C}$ NMR spectroscopy, comparing the experimental triad/tetrad resonance intensities with those calculated from a Bernoullian statistics, gave results consistent with a chain-end stereocontrol mechanism. For instance, Table 3, entry 5 (resonance, experimental/calculated): $r m r$, $0.35 / 0.39 ; \mathrm{rmm} / \mathrm{mmr}, 0.07 / 0.05 ; \mathrm{mmr} / \mathrm{rmm}, 0.08 / 0.05 ; \mathrm{mrm}+\mathrm{mmm}$, $0.50 / 0.44+0.07$. See: $(a)$ K. A. M. Thakur, R. T. Kean, E. S. Hall, J. J. Kolstad, T. A. Lindgren, M. A. Doscotch, J. I. Siepmann and E. J. Munson, Macromolecules, 1997, 30, 2422; (b) K. A. M. Thakur, R. T. Kean, E. S. Hall, J. J. Kolstad and E. J. Munson, Macromolecules, 1998, 31, 1487; (c) K. A. M. Thakur, R. T. Kean, M. T. Zell, B. E. Padden and E. J. Munson, Chem. Commun., 1998, 1913; (d) M. H. Chisholm, S. S. Iyer, D. G. McCollum, M. Pagel and U. WernerZwanziger, Macromolecules, 1999, 32, 963.

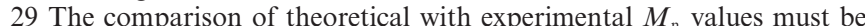
done with caution since the latter values are uncorrected and might be overestimated. However, no reliable correction factor accounting for the difference in hydrodynamic radius between PHBs and polystyrene standards has been reported to our knowledge. SEC analysis of higher molecular weight PHBs is known to be problematic. See reference $7 \mathrm{f}$ and references cited therein.

30 A. Altomare, M. C. Burla, M. Camalli, G. Cascarano, C. Giacovazzo, A. Guagliardi, A. G. G. Moliterni, G. Polidori and R. Spagna, J. Appl. Crystallogr., 1999, 32, 115.

31 (a) G. M. Sheldrick SHELXS-97, Program for the Determination of Crystal Structures, University of Goettingen (Germany), 1997; (b) G. M. Sheldrick SHELXL-97, Program for the Refinement of Crystal Structures, University of Goettingen (Germany), 1997.

32 L. J. Farrugia, J. Appl. Crystallogr., 1999, 32, 837.

33 P. Van Der Sluis and A. L. Spek, Acta Crystallogr., Sect. A: Found. Crystallogr., 1990, A46, 194.

34 A. L. Spek, Acta Crystallogr., 1990, A46, C-34. 